\title{
MONETARY POLICY AND FOREIGN EXCHANGE MANAGEMENT: REFORMING CENTRAL BANK FUNCTIONS IN MYANMAR
}

Bandid Nijathaworn, Suwatchai Chaikhor, Suppakorn Chotika-arpa, and Suchart Sakkankosone

NO. 431

May 2015
ADB ECONOMICS WORKING PAPER SERIES 
ADB Economics Working Paper Series

\section{Monetary Policy and Foreign Exchange Management: Reforming Central Bank Functions in Myanmar}

Bandid Nijathaworn, Suwatchai Chaikhor, Suppakorn Chotika-arpa, and Suchart Sakkankosone

No. 431 | May 2015
Bandid Nijathaworn (bandidn@bot.or.th) is President and Chief Executive Officer, Thai Institute of Directors. Suwatchai Chaikhor (SuwatchC@bot.or.th) is Division Chief, International Department, Monetary Policy Group, Bank of Thailand. Suppakorn Chotika-arpa (SuppakoC@bot.or.th) is Team Executive, International Strategy Division, International Department, Monetary Policy Group, Bank of Thailand. Suchart Sakkankosone (suchart53@gmail.com) is Former Senior Director, Monetary Policy Department, Bank of Thailand.

This was a background paper for the Asian Development Bank Myanmar Country Diagnostics Study. 
Asian Development Bank

6 ADB Avenue, Mandaluyong City

1550 Metro Manila, Philippines

www.adb.org

(C) 2015 by Asian Development Bank

May 2015

ISSN 2313-6537 (Print), 2313-6545 (e-ISSN)

Publication Stock No. WPS157285-2

The views expressed in this paper are those of the authors and do not necessarily reflect the views and policies of the Asian Development Bank (ADB) or its Board of Governors or the governments they represent.

ADB does not guarantee the accuracy of the data included in this publication and accepts no responsibility for any consequence of their use.

By making any designation of or reference to a particular territory or geographic area, or by using the term "country" in this document, $A D B$ does not intend to make any judgments as to the legal or other status of any territory or area.

Note: In this publication, "\$” refers to US dollars.

The ADB Economics Working Paper Series is a forum for stimulating discussion and eliciting feedback on ongoing and recently completed research and policy studies undertaken by the Asian Development Bank (ADB) staff, consultants, or resource persons. The series deals with key economic and development problems, particularly those facing the Asia and Pacific region; as well as conceptual, analytical, or methodological issues relating to project/program economic analysis, and statistical data and measurement. The series aims to enhance the knowledge on Asia's development and policy challenges; strengthen analytical rigor and quality of ADB's country partnership strategies, and its subregional and country operations; and improve the quality and availability of statistical data and development indicators for monitoring development effectiveness.

The ADB Economics Working Paper Series is a quick-disseminating, informal publication whose titles could subsequently be revised for publication as articles in professional journals or chapters in books. The series is maintained by the Economic Research and Regional Cooperation Department. 


\section{CONTENTS}

TABLES AND BOXES

ABSTRACT $v$ V

$\begin{array}{ll}\text { I. INTRODUCTION } & 1\end{array}$

II. LAYING A MACRO POLICY FOUNDATION TO SUPPORT A MARKET-BASED ECONOMY 6

III. FOREIGN EXCHANGE FRAMEWORK, OPERATION, AND EXCHANGE CONTROL 8

A. Limitations of the Foreign Exchange Auction 9

B. Moving to More Effective Foreign Exchange Management 10

C. Capital Account Liberalization and Managing Capital Flows 10

D. Sequencing Capital Account Liberalization 12

E. Access to Foreign Exchange: New Rules and Regulations 13

F. Reserve Management and Settlement 14

G. Balancing Exchange Rate Flexibility and Safeguards 16

IV. MONETARY POLICY FUNCTIONS AND OPERATION $\quad 17$

A. Macro Context of the Monetary Policy Challenge 17

B. Monetary and Exchange Rate Policy 17

C. Reserve Money Targeting and Operating Procedures 19

D. Transmission Mechanism and Money Market Development 21

E. $\quad$ More Policy Tools Are Needed for Liquidity Management 22

F. Data Requirements for Monetary Policy 24

G. Establish a Clear and Transparent Monetary Policy Process 25

H. Monetary and Fiscal Policy Coordination 25

V. $\quad$ CENTRAL BANK OF MYANMAR AS LENDER OF LAST RESORT AND ITS

DEVELOPMENT ROLE $\quad 26$

A. $\quad$ Financial Stability and Lender of Last Resort 26

B. Payment System Oversight 29

C. The Central Bank of Myanmar's Development Role 30

VI. OPERATIONAL STRUCTURE AND CAPACITY BUILDING 30

$\begin{array}{ll}\text { VII. CONCLUSION } & 34\end{array}$

$\begin{array}{ll}\text { BIBLIOGRAPHY } & 35\end{array}$ 


\section{TABLES AND BOXES}

\section{TABLES}

$1 \quad$ Myanmar's Key Economic Indicators, FY2000-FY2010 4

2 Reserve Management, Tranches 14

3 Financial Indicators, Myanmar, and Its Neighbors 18

\section{BOXES}

$1 \quad$ Recent Banking and Financial Reforms 2

2 Preconditions for Safe Capital Account Liberalization 11

3 A Strategy for the Central Bank of Myanmar's Reserve Management and Operational Arrangement $\quad 15$

$4 \quad$ Monetary Policy Tools $\quad 19$

5 Reserve Money Targeting and Implementation $\quad 20$

$6 \quad$ Money Markets and Infrastructure Needs $\quad 23$

$7 \quad$ Guiding Principles for Data Management 33 


\begin{abstract}
Myanmar's macroeconomic policy framework does not adequately support the new functions of the Central Bank of Myanmar. The monetary policy regime is deficient and institutions that complement the working of a market-based economy lacking. This paper identifies 10 priority areas for reform to allow the central bank to effectively perform its emerging new functions in support of economic growth and stability. This is a three-front effort: dismantle nonmarket arrangements, especially in the finance sector; implement a monetary policy framework and operational procedures, including financial markets development; and enhance central bank policy capacity. The latter includes elevating the policy process, central banking functions, and institutional roles to match the tasks of a modern monetary authority in a market-based economy.
\end{abstract}

Keywords: central bank, financial markets, monetary policy, Myanmar

JEL Classification: E51, E52, E58 


\section{INTRODUCTION}

Myanmar's current macroeconomic policy framework, especially concerning the conduct of monetary policy, is not supportive of a modern market economy. The main deficiencies are in the current settings of monetary policy and the lack of institutions that complement a functioning market-based economy. As a result, the economy has been operating within the limits of its own deficiencies and structural constraints. The main ones are (i) the closed structure of the economy, marked by the government's dominant role in economic decisions and resource allocation; (ii) an almost cash-based economy with a limited banking sector that impedes financial intermediation and investment; and (iii) a severe shortage of institutional capacity and human resources in the government and private sector. As a result, the economy is heavily reliant on informal markets.

In the context of macro policy, a major deficiency lies in an outdated macroeconomic policy framework that relies overwhelmingly on government's nonmarket intervention, as opposed to market signals, to guide economic activity and resource allocation. Prior to the reform, the government's fiscal operations were extensive and the Central Bank of Myanmar (CBM), as a unit of the Ministry of Finance (formerly the Ministry of Finance and Revenue), financed the fiscal deficits. The strong presence of the government was also evident in the central roles that state banks play in the economy's foreign exchange market and in credit allocation. Such structures blunt economic incentives and shaped the pattern of financial resource use in the economy.

The cost of these deficiencies has been large, both to economic performance, relative to what could have been achieved, and in the government's ability to support the private sector and maintain price stability. Myanmar's macroeconomic data from 2000 to 2010, summarized in Table 1, confirm this. Myanmar's annual gross domestic product (GDP) growth from 2000 to 2010 averaged 4.71\%, compared to the Association of Southeast Asian Nations' (ASEAN) average of $5.16 \%$ over the same period.' Myanmar's GDP growth was driven largely by an output expansion in agriculture and extractive industries - the mainstays of the country's production and exports. Private sector investment was weak, held back by poor incentives, an unfavorable business environment, and restricted access to foreign exchange. Private consumption, meanwhile, was constrained by the low growth of household incomes and widespread poverty.

International trade and investment has been held back by limited access to foreign exchange and economic sanctions. The latter, which severely depressed trade, investment, and international payments transfer, isolated Myanmar for more than 5 decades from the global economy.

Guided by the "Export First" policy to preserve foreign exchange by balancing import payments with export proceeds under an unrealistic fixed exchange rate, a system for foreign exchange allocation was introduced in July 1997. This operated via a major state bank-Foreign Trade Bank-that pooled all the foreign exchange from export earnings and allocated them to import payments through bilateral negotiations for foreign exchange between importers and exporters. The system effectively sidelined the country's private commercial banks from the largest part of the foreign exchange business, and clearly favored the government, state enterprises, and those of certain businesses. The rest of the economy, meanwhile, had to rely on the informal markets for foreign exchange. This arrangement distorted the economy in a large way, resulting in slow growth in exports and imports, with official reported trade remaining roughly in balance.

Calculated based on the International Monetary Fund (IMF) country reports for Myanmar, Article IV Consultation (various years); and World Bank, World Development Indicators for ASEAN. 
Because of subdued private sector activity, domestic demand has been the main driver of government expenditure. Given weak tax revenue (because of the low tax base), this has been financed mainly through central bank borrowing. Monetization of the fiscal deficits has sharply expanded the money supply and, in the absence of a policy to limit monetary growth, the CBM's ability to control inflation was seriously compromised. As a result, domestic inflation rose to 34\% in 2001 and $58 \%$ in the following year, further depressing private spending and economic incentives.

Economic reforms launched from 2010 aimed to correct these distortions and lay down the legal framework for the development of a market-based economy. The reform agenda focused on the finance sector and included measures to further liberalize the scope of business of commercial banks, improve the operations of the CBM and the foreign exchange market, and introduce new legislation on foreign investment and the operational autonomy of the CBM. Box 1 shows the reforms.

\section{Box 1: Recent Banking and Financial Reforms}

Since President Thein Sein came to power in 2011, a wide range of economic reforms have been implemented and are ongoing. The following looks at reforms in the banking and finance sectors, summarizing them chronologically.

\section{1}

September

October

November
Myanmar Payment Union set up to develop a payment and settlement system.

Central Bank of Myanmar (CBM) grants money changing licenses to authorized dealers. CBM grants foreign exchange licenses to authorized dealers.

CBM grants currency remittance services to private authorized banks for Myanmar workers overseas. Myanmar Microfinance Law passed.

\section{2}

January

April

July

August

November

December
CBM starts deposit auctions.

CBM starts exchange rate unification and daily foreign exchange auctions.

CBM changes its exchange rate system from a fixed exchange rate to a managed float.

Tax on transfers of export proceeds lifted.

CBM grants authorized banks permission to maintain foreign currency accounts for international banking services.

Foreign exchange management law enacted. ${ }^{a}$

Parliament approves new Foreign Investment Law.

Framework for Economic and Social Reform (FESR). ${ }^{\text {b }}$

Simplification of the reserve requirement.

\section{3}

March

July

August

November
Parliament approves minimum wage recommendations.

Parliament approves the Central Bank of Myanmar Law.

Foreign exchange interbank market launched.

Mobile banking services launched.

\section{Ongoing Reforms}

Started in 2012

Special Economic Zone Law.

Foreign banks allowed to compete in the domestic market.

Expected to finish within 2015

Establishing a real-time gross settlement system and other fundamentals supporting the payment and settlement system.

Establishing an equities exchange.

a The law removed all exchange rate restrictions and also eliminated multicurrency practices.

${ }^{b}$ Key measures under FESR include land reform, improved access to credit, and creating job opportunities.

Source: Central Bank of Myanmar. http://www.cbm.gov.mm 
The unification of the foreign exchange markets was at the heart of the banking and financial reforms. Here, the government-sanctioned market-based on the official exchange rate and the allocation system-coexisted with informal, parallel exchange rates and the presence of multiple rates was clearly a significant distortion.

In April 2012, the two markets were unified under a managed float. A daily foreign exchange auction is now held between commercial banks and the CBM, which determines official foreign exchange rates based on true market conditions. This has narrowed the gap between the official rate and the parallel exchange rate.

Greater exchange rate flexibility has also allowed the economy to adjust better to changing economic conditions via movements in the exchange rate. This reform was followed by the introduction of the Foreign Exchange Management Law in 2012 and the Central Bank Act in 2013.

Given Myanmar's long years of economic controls and isolation, these initial reforms were bold initiatives aimed at removing economic distortions and providing the legal foundations for the authorities to move toward a market-based economy. The reforms were well-received and, together with the progress made in political reform, sparked renewed interest in Myanmar and the country's economic opportunities. The reforms were quickly followed by the lifting of economic sanctions by a number of foreign governments, which improved business confidence and created a surge of interest in investment and trade by foreign investors and governments.

Thanks to these developments, the economy picked up markedly in 2012, with a more broadbased expansion of economic activities, driven by foreign investment, increased government spending, and much improved business sentiment. On the production side, the pick-up in activity included expansion in agriculture, extractive industries, and services; the latter benefiting considerably from the resurgence of foreign interest in business and tourism, as well as the influx of foreign capital. But with the economy's limited absorptive capacity, this increased demand and spending immediately put pressure on the current account, inflation, and asset prices.

From the perspective of macroeconomic policy, the reforms in 2012 have not been followed by broad-based improvement or reform in other areas of macroeconomic management and economic institutions, including monetary policy and central banking functions. As a result, the economy has failed to take full advantage of the reforms, especially exchange rate unification. The benefits of this have not trickled down to the business community and have failed to ignite or sustain a pick-up in economic activity. Furthermore, the economic activity has not been fully supported by a stable macroeconomic environment, which could have resulted had there been improvements in other areas of fiscal and monetary policy management. Indeed, there has been a conspicuous absence of momentum in private sector growth following the reforms, despite the large influx of foreign capital.

Against this backdrop, an urgent agenda is to reform the macroeconomic policy, legal, and institutional frameworks to enable the economy to leverage the benefits of existing reforms and pave the way for further ones to support the development of a market-based economy. In the current setting, given the prominent role of the CBM, a key priority is to equip the monetary authority with new capacities to perform full-fledged monetary policy and other central banking functions that support the country's growth and stability. Most important in this context are capacities to operate monetary policy, stabilize financial markets, and maintain economic and financial stability. 
Table 1: Myanmar's Key Economic Indicators, FY2000-FY2010

\begin{tabular}{|c|c|c|c|c|c|c|c|c|c|c|c|}
\hline & FY2000 & FY2001 & FY2002 & FY2003 & FY2004 & FY2005 & FY2006 & FY2007 & FY2008 & FY2009 & FY2010 \\
\hline \multicolumn{12}{|l|}{ Output and prices (\% change) } \\
\hline Real GDP growth & 5.5 & 5.0 & 5.5 & 0.0 & 5.0 & 4.5 & 7.0 & 5.5 & 3.6 & 5.1 & 5.3 \\
\hline CPI (period average) & $(1.7)$ & 34.5 & 58.1 & 24.9 & 3.8 & 10.7 & 26.3 & 32.9 & 22.5 & 8.2 & 8.2 \\
\hline \multicolumn{12}{|l|}{ Public sector (\% of GDP) } \\
\hline Total revenue & 5.3 & 4.7 & 5.0 & 4.6 & 6.5 & 6.7 & 7.7 & 14.1 & 13.1 & 10.7 & 11.4 \\
\hline Total expenditure & 13.6 & 10.5 & 8.6 & 9.5 & 11.2 & 10.0 & 11.9 & 17.9 & 15.5 & 15.6 & 16.9 \\
\hline Net lending $(+) /$ borrowing $(-)$ & $(8.4)$ & $(5.8)$ & $(3.6)$ & $(4.9)$ & $(4.7)$ & (3.3) & $(4.3)$ & $(3.8)$ & $(2.4)$ & $(4.9)$ & $(5.4)$ \\
\hline Domestic public debt & 25.0 & 22.5 & 19.5 & 19.1 & 21.3 & 19.6 & 18.6 & 16.5 & 16.8 & 18.7 & 21.0 \\
\hline \multicolumn{12}{|l|}{ Money and credit (\% change) } \\
\hline Broad money & 47.4 & 43.2 & 18.4 & 11.0 & 33.3 & 25.1 & 27.1 & 21.0 & 23.4 & 34.8 & 36.3 \\
\hline Domestic credit & 44.7 & 36.6 & 24.4 & 14.5 & 33.8 & 24.5 & 27.4 & 22.1 & 24.0 & 34.8 & 34.4 \\
\hline Private sector & 52.7 & 56.9 & 1.0 & $(36.6)$ & 39.0 & 22.2 & 16.4 & 16.7 & 16.2 & 36.9 & 65.4 \\
\hline \multicolumn{12}{|l|}{$\begin{array}{l}\text { Balance of payments (\% of GDP, } \\
\text { unless otherwise) }\end{array}$} \\
\hline Current account balance & 4.1 & $(4.3)$ & 1.7 & 0.2 & 2.4 & 3.7 & 7.1 & 0.4 & $(2.9)$ & (1.3) & (1.9) \\
\hline Trade balance & 1.3 & $(4.7)$ & 7.0 & 4.3 & 8.8 & 12.9 & 15.6 & 4.6 & 1.0 & 1.3 & 0.9 \\
\hline Exports & 25.1 & 32.1 & 33.2 & 20.8 & 27.5 & 29.5 & 35.9 & 31.9 & 23.1 & 19.9 & 17.4 \\
\hline Imports & $(23.8)$ & $(35.4)$ & $(26.2)$ & $(16.5)$ & $(18.7)$ & $(16.5)$ & $(20.3)$ & $(27.3)$ & $(22.1)$ & $(18.6)$ & $(16.5)$ \\
\hline \multicolumn{12}{|l|}{$\begin{array}{l}\text { Balance of payments (\% of GDP, } \\
\text { unless otherwise) }\end{array}$} \\
\hline Exports (\$ million) & $2,451.0$ & $2,484.0$ & $2,912.0$ & $2,818.0$ & $2,902.0$ & $3,531.0$ & $5,203.0$ & $6,446.0$ & $7,241.0$ & $7,578.0$ & $8,629.0$ \\
\hline Imports (\$ million) & $(2,319.0)$ & $(2,736.0)$ & $(2,300.0)$ & $(2,240.0)$ & $(1,973.0)$ & $(1,984.0)$ & $(2,937.0)$ & $(5,522.0)$ & $(6,938.0)$ & $(7,067.0)$ & $(8,184.0)$ \\
\hline Financial account & (1.0) & 0.0 & $(0.7)$ & $(0.2)$ & 0.6 & (1.1) & 0.4 & 3.3 & 2.6 & 4.0 & 6.8 \\
\hline Net FDI & 2.1 & 2.5 & 2.2 & 0.9 & 2.4 & 2.0 & 3.0 & 3.5 & 3.1 & 2.5 & 4.5 \\
\hline Net FDI ( $\$$ million) & 208.0 & 192.0 & 191.0 & 128.0 & 251.0 & 236.0 & 428.0 & 715.0 & 976.0 & 963.0 & $2,249.0$ \\
\hline Overall balance & (3.2) & 1.3 & $(0.7)$ & $(0.3)$ & $(0.1)$ & $(0.4)$ & 8.1 & 4.0 & 0.4 & 2.2 & 0.8 \\
\hline $\begin{array}{l}\text { Gross official reserves } \\
(\$ \text { million })\end{array}$ & 269.0 & 524.0 & 619.0 & 781.0 & 873.0 & $1,026.0$ & $2,503.0$ & $3,054.0$ & $3,629.0$ & $2,809.0$ & $3,754.0$ \\
\hline $\begin{array}{l}\text { Gross official reserves } \\
\text { (months of total imports) }\end{array}$ & 1.4 & 2.3 & 3.2 & 4.2 & 5.3 & 4.2 & 5.4 & 6.6 & 6.3 & 3.7 & 3.9 \\
\hline
\end{tabular}


Table 1 continued

\begin{tabular}{|c|c|c|c|c|c|c|c|c|c|c|c|}
\hline & FY2000 & FY2001 & FY2002 & FY2003 & FY2004 & FY2005 & FY2006 & FY2007 & FY2008 & FY2009 & FY2010 \\
\hline Total external debt ( $\%$ of GDP) & 60.8 & 78.1 & 67.5 & 45.7 & 64.3 & 58.7 & 50.4 & 40.0 & 29.0 & 36.1 & 29.0 \\
\hline Total external debt ( $\$$ billion) & $5,936.0$ & $6,042.0$ & $5,919.0$ & $6,205.0$ & $6,797.0$ & $7,038.0$ & $7,303.0$ & $8,082.0$ & $9,101.0$ & $13,800.0$ & $14,400.0$ \\
\hline Terms of trade ( $\%$ change) & 2.8 & $(23.1)$ & $(0.7)$ & 4.6 & 7.3 & 8.5 & 16.4 & 1.7 & 6.2 & 4.0 & $(2.9)$ \\
\hline $\begin{array}{l}\text { Official exchange rate (kyat- } \\
\text { dollar, end of period) }\end{array}$ & 6.7 & 6.8 & 6.2 & 5.7 & 5.6 & 5.9 & 5.6 & 5.2 & 5.8 & 5.7 & 5.4 \\
\hline Memorandum items & & & & & & & & & & & \\
\hline GDP (kyat billion) & $2,553.0$ & $3,548.0$ & $5,625.0$ & $7,717.0$ & $9,079.0$ & $12,287.0$ & $16,853.0$ & $23,336.0$ & $28,778.0$ & $34,958.0$ & $39,847.0$ \\
\hline GDP (\$ billion) & 9.8 & 7.7 & 8.8 & 13.6 & 10.6 & 12.0 & 14.5 & 20.2 & 31.4 & 38.1 & 49.6 \\
\hline GDP per capita $(\$)$ & 178.0 & 129.0 & 130.0 & 197.0 & 195.0 & 216.0 & 257.0 & 350.0 & 533.0 & 587.0 & 742.0 \\
\hline
\end{tabular}

()$=$ negative, $\mathrm{CPI}=$ consumer price index, $\mathrm{FDI}=$ foreign direct investment, $\mathrm{FY}=$ fiscal year, $\mathrm{GDP}=$ gross domestic product.

Note: Myanmar's fiscal year ends 31 March of the following year, such that FY2010 starts on 1 April 2010 and ends on 31 March 2011.

Source: International Monetary Fund, Myanmar: Article IV Consultation, various years. 


\section{LAYING A MACRO POLICY FOUNDATION TO SUPPORT A MARKET-BASED ECONOMY}

In the early 1980s, the Central Bank of Burma, as it was then known, was a full-fledged central bank with a strong reputation as a member of the Southeast Asian Central Banks Association and in the league of today's top ASEAN central banks. Since then, however, Myanmar's long period of international isolation and the increased role of the government in the economy reduced the CBM's role in economic management. Today, with the passage of the new Central Bank of Myanmar Law in 2013, the CBM has gained operational independence and is building its monetary policy framework. However, the central bank continues to suffer from inadequate tools to manage liquidity and control inflation. While an over-the-counter market exists for government treasuries, all interest rates are administratively set. There is no interbank market and the CBM does not conduct open market operations.

Building a well-functioning monetary policy framework and greater central banking capacity will require effort on three fronts. The first is to dismantle the existing nonmarket arrangements, largely in the finance sector, that have inhibited efficient functioning of financial markets and efficient allocation of financial resources. The second is to put in place a monetary policy framework, process, and procedures suitable for managing and supporting a market-based economy. The third is to enhance policy capacities at the CBM by elevating its policy process, central banking functions, and institutional roles to match the tasks of a modern central bank for a market-based economy.

From our assessment, taking the current CBM's capacities and policy process as a starting point, the reform priorities are:

- Broad-based liberalization and development of the banking sector and financial markets to support private sector activities, especially as the economy's growth shifts away from agriculture, requiring greater monetization of the economy.

- Liberalization of the foreign exchange market to improve private sector access to foreign currencies. This would replace the current allocation system with a market-based system allowing domestic commercial banks to trade foreign exchange under a policy set by the CBM, consistent with the International Monetary Fund's Article IV stipulation.

- A new monetary policy framework focusing on price stability that is operationally consistent with the managed floating exchange rate regime.

- Enhancement of the CBM's financial market's operation capacity to enable it to influencethrough market mechanisms - the economy's cost of funds and liquidity in line with monetary policy decision, and to guide the costs of the fund to the economy via an efficient transmission mechanism.

- Removal of the fiscal deficit financing role of the CBM (that is, the monetization of government debt in the primary government securities market) and replacing it with open market operations by the central bank in government securities in the secondary market. This is to provide the CBM with a key policy instrument to guide and control the country's cost of funds through a market mechanism.

- Enhancement of the CBM's ability to conduct smooth foreign exchange policy by strengthening its reserve management and intervention capabilities. This includes the unification of international reserves holdings and management. 
- Creation of macroprudential tools at the CBM to ensure better handling of the stability risk of volatile capital flows, and doing so within a policy framework that integrates monetary policy and financial policy.

- Creation of a new system of data reporting between the CBM and financial institutions that allows the monitoring of the country's economic and financial condition, and using this information to assist in the conduct of monetary policy.

Implementing reforms in these eight areas is a priority. This requires, among other things, correct sequencing and careful and well-paced dismantling of the existing distortions so as not to disrupt the real economy. For implementation, the reforms can be managed with the CBM's existing capacity, supported by a team of central bank experts. The reform challenge is achievable, and it is worth noting that a number of central banks in former ASEAN transitional economies underwent a similar reform process; for example, Viet Nam in the 1990s, Cambodia from 1995 to 1999, and the Lao People's Democratic Republic in the 1980s. Myanmar can learn from the successful experience of these countries.

The experience of these countries of moving from a highly regulated economy to a marketbased one shows reform is required in three stages. The first is the rudimentary step that equips the central bank with a basic monetary policy process and the capacity to enable it to perform essential central banking functions. For Myanmar, this will include a new monetary policy framework, backed by the CBM's capacity to operate in financial markets. In the first stage, some controls of market transactions and prices as well as deposit and lending interest rates may still be required to limit volatility and ensure an orderly market adjustment and stability. One example that could be drawn upon is the $\pm 0.8 \%$ band for the exchange rate within which authorized foreign exchange dealers can buy or sell in the retail market.

The second stage is a well-functioning monetary policy that operates almost entirely on market-based instruments and mechanisms. This presupposes that a set of market institutions and a certain level of financial market development are in place. In this stage, market-based policy instruments play a larger role than direct controls in the operation of monetary policy. But the effectiveness of market-based policy instruments is typically hampered by the evolving nature of a country's financial markets, which, at this stage, tends to lack completeness, depth, and scale. The monetary policy framework in place, however, does enable the central bank to adequately operate monetary policy and maintain economic stability. The current state of monetary policy operations in Viet Nam, Cambodia, and the Lao People's Democratic Republic are operating at this second stage.

The third stage is where monetary policy and other central banking functions are operated fully through financial markets (Thailand and Malaysia are at this stage). Here, the complexities of financial markets are such that the effects of monetary policy on the economy are transmitted through all the channels of the transmission mechanism, including price, quantity, and expectations. At this stage, global financial markets and policy spillovers become major influencers of monetary policy formulation.

Guided by these experiences, the reform of Myanmar's monetary policy framework and the CBM's capacity will also need to be tackled in stages. For Myanmar, the objective of the first step is to endow the central bank with the capacity to operate a market-based monetary policy and other central banking functions to support a market-based economy. In this context, it is our view that the priorities for the CBM at this stage will be: 
- A well-defined monetary policy framework focused on maintaining low and stable inflation, and is operationally consistent with the managed floating exchange rate regime.

- Market-based monetary policy tools to support monetary policy operations and liquidity management.

- An operating short-term money market to support the CBM's monetary policy operations and the transmission mechanism for monetary policy. This would include an interbank market for domestic liquidity, a bond market to support the CBM's open market operations, and a repo market to support liquidity management.

- Adequate capacity at the CBM to operate the managed floating exchange rate regime. This should include strengthening intervention capacity; pooling foreign exchange reserves with centralized management for liquidity and investment; back-office support for reserves management; and market operations to ensure efficiency, transparency, and good governance.

- An approval-based foreign exchange control process to support the purchase and sale of foreign exchange between banks and customers based on rules set by the CBM. This is to ensure orderly and open access to foreign exchange by the private sector for their trade and investment needs that can be supported by the country's foreign exchange reserves.

- A well-defined monetary policy process that allows monetary policy decisions to be made in a structured and credible manner. This includes a process for appointing members of a monetary policy committee, meetings at regular intervals, data and analysis, and market communication.

- A lender of last resort function for the CBM consistent with its legal role under the new central bank law, as well as the policy tools necessary for the CBM to manage the impact of large capital movements. In addition, a facility could be established to enable the central bank to perform a developmental role.

- A system of data reporting and dissemination between the CBM and commercial banks needs to be established to enable the central bank to have data of internationally accepted standards to monitor financial markets and the economy, and to provide a basis for policy decisions. The aim should be to have a data reporting standard on par with the International Monetary Fund's Report on the Observance of Standards and Codes process.

- A program of capacity building to allow the CBM's senior management and professional staff to operate within the new macroeconomic policy framework. The focus here should be the development of a core CBM team capable of operating the institution's foreign exchange and monetary policy, financial market's operations, reserve management, and supporting and making CBM policy decisions. Ideally, this should be a core team of about 20 to 25 people covering all levels of seniority to lead the transformation of the CBM.

- A set of governance principles and codes of conduct for the CBM's board and central bank staff to guide operations, build credibility, and preserve the institution's independence. The issues here will be the processes for board appointments and the working relationships among the board, management, and CBM's key policy committees, as well as the working relationships with the government, financial institutions, and the public.

Implementing these 10 areas of reform should be an immediate task for the CBM. The following section looks at the modalities of these reforms.

\section{FOREIGN EXCHANGE FRAMEWORK, OPERATION, AND EXCHANGE CONTROL}

From 1977 until the recent reforms, the official kyat exchange rate was fixed to the value of the International Monetary Fund's Special Drawing Rights. But because of the unrealistic level of the 
official exchange rate and strict controls on foreign exchange, Myanmar's economy operated with a de facto multiple exchange rate system where huge distortions, including the allocation system of foreign exchange operated by the state banks, forced the private sector to rely on informal markets for foreign exchange. To eliminate these distortions, the government unified the exchange rate market by replacing the old system with a managed float. The new system came into effect on 1 April 2012.

Under the old system, the official dollar-kyat (MK) rate was fixed at MK6.4236 to the dollar. The day after the managed float came into effect, the CBM announced the first foreign exchange auction under the new system, with the first daily fixing at MK818 to the dollar. Initially, 11 private banks holding authorized foreign exchange dealer licenses were eligible to participate, and they were later joined by three state-owned banks along with the private banks. The auction is a daily two-way trade. Participants are required to submit their sealed buying/selling orders by 8:30 a.m. and the auction results are posted on the CBM's website at 9:30 a.m. on the same day.

Actual exchange rates quoted by individual retail money changers can vary between $\pm 0.8 \%$ of the CBM's reference rate. For wholesale authorized dealers, the maximum quoted spread is currently $\pm 0.3 \%$. The Thein Phyu Pricing Committee, an authorized group of private bank foreign exchange dealers, may collectively reset its midrate in the afternoon should market conditions change significantly from the morning auction. This provides the market with a tool to adjust more flexibly to intraday volatility.

\section{A. Limitations of the Foreign Exchange Auction}

The CBM has no predetermined target for the exchange rate, and since the introduction of the auction, the kyat has gradually depreciated against the dollar. Although the transition to the new foreign exchange system went smoothly and the unification was hailed as a success, there are policy and operational limitations in the current system. These can be addressed to improve the effectiveness of foreign exchange management in the following ways:

- Transparency. Transparency of the auction process, especially information on the modalities of the process to be made public.

- Intraday volatility. As the auction is conducted only once a day, there is a risk of significant intraday volatility; this means the CBM must be ready to intervene, if needed, to contain volatility.

- Adequacy of international reserves held by the CBM. The amount of official reserves may need to be increased to give the central bank more room to stabilize the foreign exchange market. And to assure financial markets of its foreign exchange management capability, the CBM may want to increase official reserves-preferably through reserves pooling-to enhance its capacity to manage the exchange rate.

- Access to global money markets. Because of a prolonged period of economic sanctions, the CBM and domestic financial institutions have been isolated from global financial markets. The economy relies on the flows of international trade and investment for its access to foreign currency earnings and proceeds. Even though sanctions have been mostly lifted or suspended, access to global money markets is still far from normal. Local banks remain reluctant to have their dollar settlement accounts held with the Federal Reserve given uncertainty over partial sanctions by the US government and also because local banks at the early stage of their foreign exchange business tend to prefer accumulating foreign currency to strengthen their foreign exchange position rather than actively participating in the local interbank market. 
- Efficiency of markets and instruments for banks to manage liquidity. The CBM has put in place a deposit auction as an instrument for absorbing domestic liquidity both for price (interest rate) discovery and for sterilization. This allows banks to adjust excess liquidity with the CBM. However, with less-than-active participation from private banks, the deposit auction is still in its early development stage. Thus, there is room for further reform of CBM facilities to enable private banks to better adjust their liquidity needs with the central bank.

- Access to foreign exchange. This is still a problem for the private sector. Fixing it requires dismantling the central role that Myanma Foreign Trade Bank plays in the allocation of foreign exchange and replacing it with a commercially based foreign exchange operation through the banking sector as a whole.

\section{B. Moving to More Effective Foreign Exchange Management}

To improve the effectiveness of foreign exchange management and to liberalize access to foreign exchange for the private sector, the CBM could pursue further reform in the following areas:

- Increase the CBM's intervention capacity. The CBM could improve its capacity to effectively intervene in the foreign exchange market by pooling the international reserves from the state-owned banks to be centralized at the central bank with a single account and centralized reserves management. This will require a legal arrangement backed by government authority to facilitate such a transfer, with the CBM issuing central bank bills in local currency to cover the transfer.

- Enhance the ability of banks to adjust their foreign exchange positions and liquidity. Although the CBM has successfully started an interbank foreign exchange market since August 2013, its low market turnover shows that this has not been well-received by banks. Trade volume is thin and driven by just a few transactions. To further develop the interbank foreign exchange market and provide banks with more facilities to adjust their foreign and local currency positions, a number of new facilities could be introduced, such as:

(i) A swap facility as a liquidity management tool that allows the CBM to manage foreign exchange liquidity through banks, and vice versa.

(ii) Allowing and facilitating banks to enter the global foreign exchange market for better hedging and risk mitigation of banks' balance sheets.

(iii) Greater scope for foreign exchange operations by banks to allow more flexibility for authorized dealers to autonomously manage their exposure within domestic and international interbank markets.

\section{Capital Account Liberalization and Managing Capital Flows}

Before the political and economic reforms, international trade and capital movement was limited owing to sanctions. Trade and investment were small-scale and mostly with neighboring countries, such as the People's Republic of China and Thailand. Economic reforms have brought sizable capital flows back to Myanmar and ignited private sector investment. One important consequence of the inflows has been a worsening of the current account balance that reflects a sharp rise in investment activity and in the imports of capital goods for mega-project investments. The deficit in the external current account is expected to rise further on the back of the country's positive medium-term outlook and possible further lifting of economic sanctions. These deficits will need to be financed either by foreign direct investment (FDI) or by other forms of foreign capital. Therefore, accompanying the 
current account deficits, continuing capital inflows could pose serious stability risks to the economy. These include overheating, inflation, asset-price bubbles, financial instability, and sudden reversals in capital flows. These risks need to be monitored and managed.

To safeguard the economy, especially during surges in capital flows, the CBM needs to be equipped with a variety of instruments that can be used to discourage excessive inflows of foreign capital, especially short-term capital, or deal with the macro implication of such flows, or both. Many of these instruments will be monetary policy and the macroprudential tools that the CBM already has in place to maintain price and financial stability. But in addition to these instruments, the CBM can effectively control foreign capital flows in and out of Myanmar with its capital account liberalization policy. This is another important policy area that the central bank needs to develop by defining clearly the appropriate degree of openness for capital flows, both on the inflow and outflow sides. This means rules and regulations that set the conditions for foreign investors to bring capital into Myanmar and for domestic residents to take capital out of the country.

The benefits and risks of capital account liberalization are well-understood. On the inflow side, capital account liberalization not only enhances efficiency in resource allocation, but also improves the competitiveness of the local finance sector. Capital inflows in the form of FDI help transfer technology and management practices, help develop the finance sector, instill macroeconomic policy discipline, and promote trade and investment efficiency. But capital account liberalization also brings risks; to manage them, the CBM will have to decide on the extent of liberalization. Furthermore, the scope of international capital flows should be consistent with the CBM's ability to manage the risks. Box 2 presents a guide for "safe" capital account liberalization.

\section{Box 2: Preconditions for Safe Capital Account Liberalization}

Stable macroeconomic and financial conditions. A credible exchange rate arrangement that is supported by adequate reserves can reduce risks related to capital flow volatility. Low and stable inflation can help reduce the risk of capital inflow surges that stem from carry trade and capital flight triggered by worsening market expectations. Building and maintaining macroeconomic and finance sector buffers can also reduce the risk of capital inflow surges. A sustainable fiscal position and manageable public sector and external debt reduce the likelihood of adverse macroeconomic effects of capital flow retrenchment while providing room to accommodate private sector outflows.

Finance sector ability to deal with increased capital flow volatility. Liberalizing and developing the finance sector, and ensuring sound governance and risk management in financial institutions, helps strengthen the ability to deal with capital flows. Evaluating the resilience of banks' balance sheets to shocks in capital flows requires attention in the following issues: (i) the level of reliance on deposits, (ii) adequacy of net open foreign exchange position limits or exchange rate risk management practices, (iii) credit risk associated with exchange rate depreciation due to a large share of foreignexchange-denominated or inflation-linked loans, and (iv) high levels of nonperforming loans.

High standards of governance and disclosure. Adherence to international accounting standards, transparency, and shareholder protection standards facilitates the liberalization of foreign direct investment and portfolio flows. It also allows for proper pricing of stocks and securities and reduces the vulnerability of finance and nonfinance corporate sectors to risks related to greater openness.

Strong finance sector regulatory standards and effective supervisory framework. Adequate micro and macroprudential regulations can significantly contribute to containing the risks of greater openness. Cooperation agreements with supervisory authorities of other countries can facilitate the detection and management of financial stability risks. An adequate deposit guarantee framework can help local banks retain residents' deposits. Proper crisis preparedness and resolution frameworks gain importance in a context of increased capital flow volatility and potential contagion. Adequate prudential regulations need to be in place on institutional investors' foreign investments before liberalizing capital outflows. Reforms also need to address the risk that operations through the informal finance sector can undermine the effectiveness of the prudential framework in the formal finance sector. 
Box 2 continued

Efficient monitoring system. Reporting and information systems should be put in place for monitoring factors contributing to capital flow movements to assess the potential risk of financial system instability and the necessity of temporarily reimposing capital flow management measures.

Source: International Monetary Fund 2013.

\section{Sequencing Capital Account Liberalization ${ }^{2}$}

A good approach to capital account liberalization is to do it in stages, beginning with a small opening then gradually increasing its scope. This applies both to the liberalization of capital inflows by foreigners and capital outflows by residents. The rule of thumb is: "long-term before short-term, FDI and other nondebt before debt, and inflows before outflows." The sequencing must be done in such a way that the preconditions underlying each stage are identified, beginning, obviously, with the supporting reforms. Putting conditions on capital account transactions will help the CBM to manage the exchange rate and ensure effective transmission of monetary policy. The conditions underlying the sequencing, meanwhile, will help guide the CBM in responding to financial market's developments, as certain capacities in the domestic financial markets need to be established before moving from one stage to another. We now summarize this process.

\section{Prior to Liberalization: Supporting Reforms}

The immediate priority is to set up a facility for banks to manage and hedge their foreign exchange exposure domestically. Banks should be allowed to manage their foreign exchange liquidity among themselves. Introducing the foreign exchange interbank market would be the major initial step toward greater flexibility for banks. The CBM should also introduce more flexible instruments and other market supportive fundamentals; for example, currency swap markets, forward markets, a reference rate, and a yield curve.

\section{Stage I}

Liberalize FDI inflows and certain short-term bank-related flows to facilitate trade and financial transactions for clients of financial institutions (for example, trade finance, and allowing banks to open accounts with banks abroad). This stage also lays the groundwork for further liberalization by introducing international accounting standards and improving national statistics. The monetary framework and finance sector regulation also need to be strengthened at this stage.

\section{Stage II}

Liberalize FDI outflows and inflows into traded securities (for example, listed bonds and equities). This stage introduces FDI outflows and long-term portfolio flow liberalization. Some short-term flows can also be liberalized at this stage. Liberalizing inflows into equities may present fewer complications than bonds, given the potential of equities for greater risk-sharing and market-deepening. Bond market development could also benefit from foreign participation enlarging the investor base. Some countries have taken advantage of liberalizing inflows into traded securities to lengthen maturities (for example, initially allowing inflows only for long maturities). In this stage, prudential controls on banks' open

2 This mainly draws on International Monetary Fund (2013). 
positions will need to continue, especially to limit the large-scale use of short-term foreign currency borrowing to fund domestic currency lending, along with prudential rules on domestic lending in foreign exchange.

\section{Stage III}

Progressively lift controls on outflows, and allow greater participation of foreign investors in other assets. This stage eliminates all remaining controls after developing the financial markets and further strengthens the finance sector by implementing prudential regulations and supervision to ensure the risk management of international capital flows.

\section{E. Access to Foreign Exchange: New Rules and Regulations}

Foreign exchange deregulation and capital account liberalization help international trade payments, foreign investment, and economic development. However, they also bring risks that include greater volatility in the macroeconomic system and more vulnerability to crises. Deregulation of the foreign exchange business can be the next key policy reform in Myanmar, and ensuring that the benefits of this reform trickle down fully to the business community while maintaining economic and financial stability. In these circumstances, a new system of foreign exchange allocation is needed, as already discussed. Ideally, all foreign exchange transactions would be conducted through commercial banks and authorized nonbanks, with any other transactions requiring approval from the CBM.

The following is a brief description of a system of foreign exchange rules and regulations, similar to that of Thailand, which the CBM could adopt. It is an open system that involves commercial banks selling and buying foreign exchange directly with their customers under rules and regulations set by the central bank.

- Foreign currency regulations. Foreign currency is normally transferred or brought into the country without limits, though caps may be imposed in certain circumstances, subject to rules set by the central bank. Any person receiving foreign currency from abroad is required to repatriate the funds immediately and sell them to an authorized bank or deposit them in a foreign currency account with an authorized bank within a certain number of days. Exceptions are made for foreigners staying for short durations, such as employees of embassies and international organizations.

- Purchase of foreign currency. Private firms should generally be allowed to purchase foreign currency from authorized banks after submitting documents indicating international trade and investment needs or they could hedge against foreign exchange risk.

- Foreign currency account with authorized banks. In Thailand, residents may hold foreign currency accounts with authorized banks, and deposit or withdraw funds under certain conditions. There are limits on currency deposits and withdrawals to prevent speculation, and both transactions need supporting documents. Nonresidents may hold foreign currency accounts with authorized banks without limits, but the funds must originate from aboard.

- Regulations for trade and services. Export proceeds must be repatriated after payment is received or within a certain number of days from the export date. The proceeds must be sold to or deposited in a foreign currency account with an authorized bank. Importers may purchase foreign currency from licensed banks or make withdrawals from their own foreign currency accounts (if allowed) for import payments upon submission of supporting documents. Letters of credits may also be opened without authorization. 
- Repatriating proceeds from services. Beyond a certain amount, these must be immediately repatriated, with proceeds from services treated in a similar manner to export proceeds. Outward remittances by nonresidents are permitted for items of a noncapital nature, such as service fees, interest, dividends, profits, or royalties, provided that supporting documents are submitted to an authorized bank. Traveling expenses or educational expenses of residents are also freely allowed upon submission of supporting documents.

- Foreign investments and loans. Transfers in foreign currency for direct and portfolio investments into Myanmar are freely allowed. But proceeds must be surrendered to an authorized bank or deposited in a foreign currency account with authorized banks.

- Repatriation of investment funds and repayment of overseas loans. These can be remitted freely on submitting supporting documents to an authorized bank. For the repatriation of investment funds, evidence of the sale or transfer of investments must be submitted. For loan repayments, proof of the inward remittance of loans and loan agreements must be submitted.

- Central bank approval. Transfers for purposes other than those indicated in the aforementioned points require approval from the central bank.

- Reporting system. Any person purchasing, selling, depositing, or withdrawing foreign currency with an authorized bank exceeding a certain amount is required to report such transactions to the authorized bank in a form prescribed by the central bank. The reports must contain details that help the central bank to monitor foreign exchange transactions, possible market speculation, and provide the database for balance of payments compilation.

\section{F. Reserve Management and Settlement}

Reserve management is a key function of most central banks, the CBM included, and its objectives need to be clearly defined. These typically include having sufficient liquidity to implement monetary and exchange rate policies, facilitating international trade and finance, functioning as a store of wealth, enhancing market confidence, and backing up against currencies in circulation. Once the objectives are defined, the management of reserves may be conducted in multiple tranches with different asset compositions and durations to meet specific objectives. After reserves pooling, and with a larger stock of official reserves, Table 2 shows how typical reserves segregation or tranches can be organized:

Table 2: Reserve Management, Tranches

\begin{tabular}{|llll|}
\hline \multicolumn{1}{|c|}{ Tranches } & \multicolumn{1}{c|}{ Objective } & \multicolumn{1}{c|}{ Investments } \\
\hline Liquidity & $\begin{array}{l}\text { Implement monetary and exchange rate } \\
\text { policies }\end{array}$ & $\begin{array}{l}\text { Very liquid instruments } \\
\text { Short investment horizon (less than 3 } \\
\text { months) }\end{array}$ \\
\hline Investment & $\begin{array}{l}\text { Second line of defense, utilized in } \\
\text { implementation of policies once liquidity is } \\
\text { depleted }\end{array}$ & $\begin{array}{l}\text { Liquid instrument } \\
\text { Reserves over and above amount necessary } \\
\text { to implement policies in a typical economic } \\
\text { cycle }\end{array}$ & $\begin{array}{l}\text { Medium investment horizon (up to 1 } \\
\text { year) }\end{array}$ \\
\hline & $\begin{array}{l}\text { Less liquidity requirement } \\
\text { Excess }\end{array}$ & $\begin{array}{l}\text { Long investment horizon (anything up to } \\
\text { 5years) }\end{array}$ \\
\hline
\end{tabular}

Source: Authors.

The CBM must also decide the unit of account on which to value investment and reserves holdings. This is generally linked to specific objectives for holding reserves. For example, in the liquidity tranche, the US dollar is the typical base currency of choice because it is also the intervention currency. However, for the investment tranche, where emphasis is more on safety, with the possibility 
of converting into the US dollar if needed, the base currency can be other currencies or a basket of currencies. Finally, for the excess tranche, the choice of unit of account and base currency is determined by the objective. If the objective of the tranche is to preserve wealth in local currencies, then it would also be appropriate to have the local currency as the unit of account.

Reserve management can either be done within the CBM, or managed by professional managers, depending on the capacity at the CBM and the openness surrounding the issue of reserve management. In all cases, the central bank will also need to decide on two more things that central banks use in managing reserves. It will need to set an acceptable risk level that defines the maximum risk and loss the CBM can take. This is usually expressed in terms of the probability of non-negative returns of the total portfolio. It will also need to set the asset universe that defines a space of investable assets based on a trade-off of risk and return. For illustrative purposes, a reserve management strategy for the CBM and the required operational structure is summarized in Box 3.

\section{Box 3: A Strategy for the Central Bank of Myanmar's Reserve Management and Operational Arrangement}

\section{Investment Strategy}

Several basic elements need to be clearly identified to conduct reserve management. The following outlines the typical strategic framework for effective reserve management:

Return on investment. Reserve management can be accomplished through either one or a combination of these approaches:

Passive management (or indexing). Invest as close to the benchmark with as little deviation as possible. In this approach, management does not take additional risk and the return will be very close to the benchmark return. This approach is sometimes preferred if it is assumed that the benchmark is already an optimized allocation, as it would be with market efficiency. This approach also is the least costly.

Enhanced indexing. Because the market is not always efficient, there may be an opportunity to deviate from the benchmark. A slight deviation means reserve managers take on market risk, measured in terms of track error (TE) or the amount that the portfolio return is expected to deviate from the benchmark return. Typically, the decision to deviate can be based on differences in asset price from their underlying fundamental value or from market assessment, both of which could be changing over time. Hence, this approach requires increased costs for analysis, monitoring, and exposure management.

Active management. Typically found in the realm of private sector fund managers, this involves active deviation from benchmark or the utilization of TE to achieve greater returns. This approach is costly, not only in terms of the operating cost needed to reward fund managers, but also in terms of the possibility of losses relative to the benchmark. As such, it may not be fully suited to the CBM, particularly in terms of remuneration.

Another dimension that can contribute to return on investment is the decision between internal and external management. Factors that need to be taken into consideration include: fees, technology transfer, and mandate.

Liquidity for immediate use. The size of the liquidity tranche will need to be identified based on policy needs. The larger the tranche, the greater the ammunition to achieve required monetary and exchange rate policies. However, tranches with an excessive size can be costly, as shorter-dated assets generally have lower returns. Constructing a benchmark for this tranche will be a product of policy needs as well as diversification along different maturities. The issue of operational burden is also important. Too short maturities will increase the frequency of rollovers. 
Box 3 continued

Risk management strategy. Risks include market risk, country risk, counterparty risk, and settlement risk. It is important to begin with an understanding of the dimensions of exposure at all levels. Each risk will have its respective matrices to capture exposure. It is up to the middle office to set out the guidelines or operating band that need to be adhered to, and for the compliance officer to constantly monitor that these limits are not breached.

\section{Governance and Work Process}

The internal work process can be classified into three functional groups:

Front office. Responsible for investment decisions, including assessing the economic and financial outlook, forecasting/valuation of financial instruments, formulating investment strategies, and trading to capture opportunities or to rebalance portfolios.

Middle office. Responsible for risk management that includes constructing benchmarks; setting investment limits; compliance, monitoring, and the reporting of risk exposure. It is necessary to create different reporting lines between front and middle offices to create checks and balances. However, segregation has efficiency costs.

Back office. Responsible for trade settlement and keeping records of transactions and portfolio holdings. These functions can either be combined with the middle office or can be part of a bank-wide accounting department. The function of settlement and fund transfer is an integral part of the process; thus, even though the settlement function may be handled by a different department, it needs to be close to the front and middle offices. An information system that can support straight-through processes and alleviate some of the internal logistics of trade flow operation is also needed. The back office, in conjunction with the middle office, is also responsible for custodial management of foreign assets. Both offices need to function in tandem with the counterparty custodian to settle trades. Transparency and accountability must be built into the reserves management process.

Source: Authors.

\section{G. Balancing Exchange Rate Flexibility and Safeguards}

The exchange rate plays an important role in a small, open economy. It is an important channel of monetary policy transmission and an effective shock absorber for unfavorable domestic and external volatility, as excessive exchange rate volatility can pose a serious threat to the economy. For this reason, central banks have to maintain a degree of exchange rate stability by keeping the volatility at levels the private sector can manage.

Yet, exchange rate flexibility is also a key mechanism allowing the economy to adjust to shocks, which means that central banks must strike a proper balance between flexibility and stability. In general, foreign exchange intervention, if needed, should focus on keeping volatility at a level that will allow economic agents time and room to adjust. And in times of large and sudden volatility, it must be supported by a set of capital account measures. As a guide to foreign exchange operations, the central bank must remain vigilant for any misalignment of economic fundamentals; that is, whether the exchange rate deviates markedly from an equilibrium level consistent with economic fundamentals. This points to the need for the CBM to do research and have a view on the equilibrium levels of the exchange rate for policy management purposes.

To this end, the CBM needs a timely and reliable data system with a full span of coverage to monitor foreign exchange market conditions closely. To achieve this, the central bank may require commercial banks and other participants to report their foreign exchange transactions in varying detail according to type of players (residents, nonresidents, interbank); purpose of transaction (trade, portfolio investment); amount of trade and settlement date, and so on. Intermarket links (for instance, 
stock and bond markets) and market intelligence (such as significant bulk transactions, news, and rumors), market theme, and trading views are also essential for the monitoring system. On this, tradeoffs between accuracy, timeliness, and burden of reporting should be kept in mind. It would also be useful to develop models that project the balance of payments outlook and fund flows to guide the CBM's thinking on foreign exchange movements and management.

\section{MONETARY POLICY FUNCTIONS AND OPERATION}

\section{A. Macro Context of the Monetary Policy Challenge}

The outlook for continued strong growth in Myanmar poses at least five immediate challenges to the CBM in managing the economy. The first is inflation, which is set to rise, reflecting an interaction of greater demand-pull pressure from the expanding economy and a cost-push pressure from increases in labor costs, at least in the next several years. A possible dismantling of price controls going forward is another factor that could add to future inflationary pressure. In addition, the CBM will need to manage banks' credit expansion to ensure sustainable growth of domestic demand.

The second challenge is ensuring proper credit allocation by the banking sector, especially to priority sectors. The third is the implication of rapid growth for the country's investment and savings gap through rising current account deficits, which can threaten external stability. The fourth is the risk to financial stability from large and volatile capital flows in the open economy that is increasingly integrated with the global economy. And the fifth is the need to develop a funding market for the government to finance its infrastructure investments and the associated fiscal deficits from sources other than the central bank.

\section{B. Monetary and Exchange Rate Policy}

Monetary and exchange rate policies typically are the responsibility of central banks. The unification of exchange rates in April 2012 and the CBM's preparation for the introduction of monetary targeting as a framework for monetary policy were a great first step. Under the new managed float exchange rate regime, a well-defined monetary policy framework is required. One likely complication, as noted, is that closer integration of the financial market with the global market will induce more capital inflows to the economy, which can induce volatility. Monetary policy and foreign exchange policy, therefore, need to be closely aligned to stabilize possible external shocks.

To buffer external shocks, the CBM will need to have the right combination of foreign and domestic assets as components of the monetary aggregate to be targeted while letting the exchange rate adjust. The sustainability and effectiveness of currency interventions will hinge importantly on the size of the official reserves available relative to market flows. In countries with limited official reserves, as in Myanmar, central banks need to support exchange rate management with monetary policy to deal with external shocks. A key question is how to assure the best combination of the two policies, to which there is no precise answer. But in this regard, good market information and an effective reporting system are indispensable for making good policies.

Putting in place a well-defined monetary policy framework-a first step, as noted-involves consideration of both an appropriate monetary target and policy implementation. Choosing an intermediate target for monetary policy is normal for central banks. They need this target to manage monetary policy and a set of policy instruments to achieve it by managing liquidity consistent with the 
monetary target. From our assessment, the CBM understands well the central bank's role in safeguarding economic stability and the need for an appropriate monetary policy framework to ensure price stability. The CBM also understands how to determine the intermediate target for monetary targeting and the importance of the policy transmission mechanism.

Even so, monetary policy in Myanmar is not yet fully and formally equipped for implementation, because of the lack of a financial market infrastructure and the institutions needed to operate market-based monetary policy (Table 3). The country's financial market is narrow and shallow, and banks have a limited role in supporting the real economy. Myanmar's M2-to-GDP ratio is among the lowest in ASEAN. The limitations posed by a lack of monetization need to be overcome-through financial market development and liberalization-to allow a market-based monetary policy and enable banks to provide the breadth and depth of services that the private sector needs. It is also necessary to develop adequate capacity for staff at both the CBM and commercial banks to operate and interact in the financial markets.

In choosing appropriate monetary targets, it is important to note that financial liberalization and growth will inevitably mean a less stable relationship between the monetary target and real sector activity, at least initially. It is therefore our view that reserve money-the sum of the central bank's money and foreign assets-will be a more suitable target for monetary policy than other monetary aggregates. This is simply because reserve money is more controllable by the central bank.

Table 3: Financial Indicators, Myanmar, and Its Neighbors

\begin{tabular}{|c|c|c|c|c|c|c|c|}
\hline & 2007 & 2008 & 2009 & 2010 & 2011 & 2012 & 2013 \\
\hline \multicolumn{8}{|c|}{ M2/gross domestic product } \\
\hline Cambodia & 32.2 & 28.4 & 37.5 & 41.6 & 39.1 & 50.0 & 53.6 \\
\hline Lao PDR & 24.2 & 25.0 & 31.9 & 38.0 & 42.1 & 49.1 & 50.0 \\
\hline Myanmar & 18.8 & 17.2 & 19.4 & 23.6 & 26.4 & 36.7 & 36.3 \\
\hline Viet Nam & 100.6 & 93.7 & 105.6 & 114.9 & 99.8 & 106.5 & 117.0 \\
\hline Thailand & 106.4 & 109.1 & 117.0 & 116.1 & 128.2 & 131.1 & 134.5 \\
\hline Malaysia & 125.2 & 119.6 & 139.2 & 133.6 & 137.9 & 141.1 & 143.8 \\
\hline \multicolumn{8}{|c|}{ Bank branches per 100,000 adults } \\
\hline Cambodia & 3.0 & 3.1 & 3.9 & 4.0 & 4.2 & 4.4 & $\ldots$ \\
\hline Lao PDR & 2.1 & 2.1 & 2.3 & 2.5 & 2.5 & 2.7 & $\ldots$ \\
\hline Myanmar & 1.4 & 1.5 & 1.5 & 1.5 & 1.7 & 1.9 & $\ldots$ \\
\hline Viet Nam & $\ldots$ & 3.3 & 3.3 & 3.2 & 3.6 & 3.2 & $\ldots$ \\
\hline Thailand & 9.8 & 10.4 & 10.9 & 11.2 & 11.5 & 11.8 & $\ldots$ \\
\hline Malaysia & 17.2 & 20.8 & 20.7 & 20.3 & 20.2 & 19.9 & $\ldots$ \\
\hline
\end{tabular}

... = data not available, Lao PDR = Lao People's Democratic Republic.

Sources: Asian Development Bank, Key Indicators for Asia and the Pacific 2014 for M2/gross domestic product for Lao PDR and Myanmar; for all others, World Bank, World Development Indicators (accessed December 2014).

Monetary policy based on targeting reserve money is compatible with Myanmar's current circumstances, as well as the CBM's operational capacity (Box 4). But given the likelihood that 
financial liberalization and capital flows will partly destabilize the relationship between reserve money and ultimate goals-making movements of the reserve money aggregate more volatile-the CBM should, in the initial stages of monetary policy development, announce the reserve money path as a projection, not a hard target. If the CBM misses the projection, the path can be reset to fit conditions. This will help avoid loss of credibility, build market confidence, and allow the CBM to operate monetary policy more flexibly. Still, the term "monetary target" should be reintroduced as soon as the CBM's financial market operations become more settled and its ability to control the reserve money aggregate is established.

\section{Box 4: Monetary Policy Tools}

Although broad, the monetary policy instruments used by a central bank can be grouped into three main categories: reserve requirements, open market operations, and standing facilities.

Reserve requirements. A central bank may require deposit money banks to hold a fraction of their reserves as vault cash or deposits with the central bank. Reserve requirements limit the amount of loans banks can make to the domestic economy and, thus, money supply.

Open market operations. A central bank buys or sells securities to the banking and nonbanking public, typically treasury bills or central bank bills.

Standing facility. A_central bank sometimes provides credits to deposit money banks, thus affecting the level of reserves and, hence, the monetary base.

These three sets of instruments are market-based. However, many central banks in developing countries also use nonmarket instruments to influence policy operation and financial resource allocation. Examples include:

Credit allocation. In countries where the supply of savings falls short of demand or banks are reluctant to extend credit due to the high costs of credit or the risk profile of customers, a central bank can intervene in the credit market by providing loans to priority sectors or requiring banks to provide loans to specific sectors.

Moral suasion. Because many central banks also regulate and supervise banks' operations, they can persuade banks to follow certain paths, such as credit restraint or expansion, or increase savings mobilization.

The monetary policy instruments used by a central bank depend on the level of development of the economy, especially its finance sector.

Source: Authors

The initial replacement of a target with a projection must be clearly communicated to the market. Thereafter, once reserve money targeting takes hold as a workable monetary policy framework, the CBM can proceed to target broader monetary aggregates. The appropriate choice of the new monetary target will depend on the relationship between the new target and aggregate demand; on the stability of that relationship, especially in the long-term; and on the CBM's ability to control the new target. Often, research is required to provide empirical evidence in support of the selection decision.

\section{Reserve Money Targeting and Operating Procedures}

Operating procedures refer to the day-to-day management of monetary conditions consistent with the overall stance of monetary policy. As a core function of monetary policy, it involves the central bank's choice of operating target and the frequency of its money market operations. The former, as the beginning of monetary transmission, is crucial. The operating target for the CBM monetary policy is reserve money. The CBM's actions influence the movement of reserve money and the final outcomes 
for the economy, as do the responses of the financial markets and the private sector. As ultimate policy goals, the CBM initially should set a broad combination of price, growth, and external stability. If the central bank sticks solely to targeting prices and the increase in inflation is not linked to the demandpull pressure, tight policy may limit growth. To set goals, the CBM needs to balance and prioritize these three goals, a demanding task.

To implement reserve money targeting, the CBM needs a well-defined technique to project the economy's key economic variables, such as GDP, prices, the balance of payments, and fiscal financing (Box 5). The CBM would then be required to translate these projections into a consistent reserve money target. To maintain the desired path for reserve money, it will have to manage liquidity by controlling the aggregate supply of bank reserves (that is, financial institutions' deposits at central banks). Liquidity forecasts are therefore essential for effective liquidity management because they indicate to the central bank the appropriate size and maturity for market interventions. The amount of liquidity intended to be drained or injected at each maturity should be carefully thought out. In practice, market conditions will give the CBM some flexibility on the amounts and maturities. Temporary liquidity surplus or shortage should be managed via short-term instruments. If any excess or shortage in liquidity is more structural in nature, longer term instruments will be more appropriate. The use of a combined set of monetary policy instruments is therefore important and can be aligned to complement and enhance liquidity management. This will be particularly helpful when there is clear market segmentation among players in the financial markets. Such information can help ensure a smoother distribution of liquidity in the system. For example, central banks can conduct open market operations through bilateral repurchase operations in which only selected banks are appointed as primary dealers.

\section{Box 5: Reserve Money Targeting and Implementation}

\section{Box Figure 5.1: Monetary Policy Framework and Its Implementation}

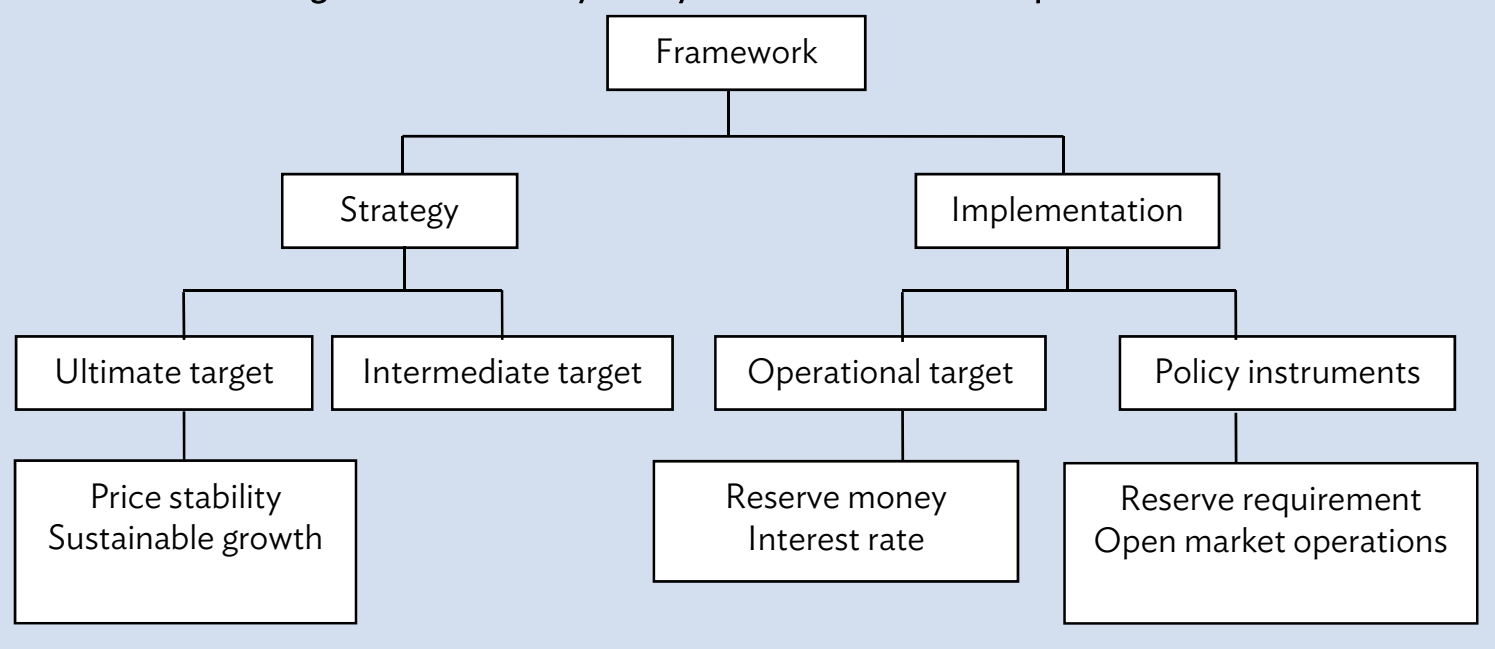

A monetary policy framework consists of two steps: making a strategic choice about the ultimate and intermediate target, and implementing the policy to achieve the target by employing monetary policy tools (Box Figure 5.1). The key steps to implement reserve money targeting include the following: 
Estimation/projection of the demand for money. Demand for money can be explained by a number of theoretical hypotheses. Money demand function are widely adopted for empirical estimation/projection of money demand. ${ }^{a}$ To estimate reliably a demand for money equation there must be a relatively stable relationship between money and other macro variables. If the demand relationship is not stable, it will be more difficult for a central bank to achieve its ultimate goals.

Normally, the estimation of the demand for money is done annually because of data limitations. The next step is to transform the annual demand for money into monthly or daily estimates to guide a bank's day-to-day operations.

Liquidity forecast. A liquidity forecast is needed to provide information for decisions on the volume, maturity, and frequency of operations designed to manage and balance market liquidity. A simplified central bank balance sheet normally provides a good basis for forecasting liquidity. With a simplified balance sheet, a central bank can estimate the quantity of liquidity (net currency position) by projecting the other items in the balance sheet, as shown in Box Table 5.1.

\begin{tabular}{|l|l|}
\hline \multicolumn{2}{|c|}{ Box Table 5.1: Simplified Central Bank Balance Sheet } \\
\hline \multicolumn{1}{|c|}{ Assets } & \multicolumn{1}{|c|}{ Liabilities } \\
\hline Net foreign assets & Currency in circulation \\
\hline Net claim on government & $\begin{array}{l}\text { Deposits from financial institutions } \\
\text { of which: required reserves } \\
\text { Free reserves }\end{array}$ \\
\hline $\begin{array}{l}\text { Net claim on private sector } \\
\text { (liquidities injection/absorption) }\end{array}$ & \\
\hline Other net assets & \\
\hline $\begin{array}{l}\text { a See Liang, X. n.d. Analysis of Money Demand Theory. web.cenet.org.cn/upfile/56317.pdf } \\
\text { Source: Authors. }\end{array}$
\end{tabular}

\section{Transmission Mechanism and Money Market Development}

A lack of active money markets is a major constraint to the implementation of market-based monetary policy in Myanmar. The interbank market is illiquid, with only a few banks participating. Banks normally adjust their liquidity with the CMB through the deposit/credits auction window. The CBM administratively sets interest rates on deposits and credits. Nonmarket interest rate setting and the underdeveloped nature of the money market seriously inhibit the effectiveness of monetary policy, since policy changes cannot be transmitted to the real sector.

This means that even though the CBM could meet the reserve money target, it cannot be certain that the corresponding output or price trajectories will be achieved in the absence of links between the policy rate in the deposit/credits auction and the interest rate in the credit market. The CBM therefore urgently needs to develop more liquid and active money markets in Myanmar, with the interbank market a priority. Moreover, uncoordinated changes in reserve requirements independent of monetary policy could add to the volatility in the money market. All policy instruments need to be aligned under a common monetary policy stance.

The money markets, including the interbank market, are typically over-the-counter markets. Interbank loans are for maturities of 1 week or less, mostly overnight. The banking sector consists of 4 state banks and 19 private banks, which together are sizable in terms of counterparties in the interbank market. The financial crisis in 2003, however, left a bad legacy of banks doing business among themselves in the interbank market. The deposit auction facility at the CBM is another factor that has discouraged banks from using the interbank market for liquidity. This is because banks can adjust their 
short-term liquidity needs though the auction window without counterparty risk. To encourage interbank market activity, which is essential to the development and the resilience of banks in Myanmar in the longer term, the central bank will have to modify and transform the auction facility into a last-resort window. Banks, meanwhile, should be encouraged to adjust their short-term liquidity needs through the interbank market and a penalty interest rate should be applied for banks seeking funds from the CBM's window.

A repurchase (repo) market should also be established to help banks manage short-term liquidity. Transactions in the repo market typically use government treasury bills for collateral. But other types of bills, such as state enterprise bills and corporate bills, can also be used if available. The repo market can resolve counterparty risk, which is a key concern of interbank transactions. Repos could include transactions between the CBM and banks, and between banks themselves. Notification and a market code of conduct are required for transparent operations in the repo market. A bond depository and paperless settlement are also required to facilitate a modern repo market.

\section{E. More Policy Tools Are Needed for Liquidity Management}

The main instruments of monetary policy at the CBM, as noted, include direct controls on lending and deposit rates, quantitative controls on credit (credit ceilings), use of central bank bills, prescribed liquid asset ratios or reserve requirement, and moral suasion. But such tools are insufficient for effective monetary policy. Instead, the deposit auction and the interest rate ceiling are the main instruments used by the CBM for policy operations. Reserve requirements are used mainly for prudential purposes and not for monetary policy. For more effective liquidity management and policy operation, reserve requirements should be used more effectively for monetary policy.

The liquidity ratio, currently in place, could serve the need for prudential regulation. Options include setting only one reserve requirement ratio (instead of having multiple ratios depending on the deposit-to-capital base) and only current account balances at the CBM. These and vault cash should be made eligible reserve assets, while government securities should be excluded. The reserve maintenance period could be lengthened beyond 1 week to allow for more flexibility in reserve averaging and to reduce interest rate volatility in the money market.

Open market operations need to be strengthened (Box 6). The CBM's only current liquidity management tool is a loan window, a liquidity injection operation conducted at a fixed rate of $10 \%$. With the foreign exchange auction in place and the potential need for the CBM to buy foreign exchange, a liquidity absorption tool will be necessary. The CBM is well-positioned to conduct open market operations, as the central bank and other banks hold plenty of treasury bills that could be used for open market operations. It is also possible for the CBM to issue central bank bills to sterilize its interventions in the foreign exchange market. The central bank can buy and sell treasury bills outright for monetary policy purposes, and it can operate monetary policy through the repo market once that market is in operation. In this context, the CBM should act as the treasury bills registrar for the government. 


\section{Box 6: Money Markets and Infrastructure Needs}

Money markets deal with short-term lending and borrowing. They are often used as a solution to the short-term cash needs by governments, large institutions, and, sometimes, individuals. There are two types of money markets: foreign exchange markets and local currency markets.

The foreign exchange market is over-the-counter, and its major players are usually commercial banks. Transactions in the foreign currency market normally include spot transactions for immediate delivery, transactions in advance (forward), transactions that swap foreign currency with domestic currency for a period (foreign exchange swaps), and derivatives transactions in foreign currencies that include foreign exchange options and cross-currency swaps.

The local currency market is for borrowing and investing domestic currency funds for terms not exceeding 1 year. Transactions in the money market cover unsecured loans between banks, buying and selling short-term debt instruments, such as treasury bills, bonds, promissory notes between banks, and collateralized borrowing and lending based on securities or debt papers, as is the case of the repo market. Money markets provide central banks a key platform for operating monetary policy.

A sound money market needs supporting infrastructure, including:

- A sizable number and variety of issuers (supply side) and investors (demand side) with different risk profiles and views about the market will contribute to high trading activity and liquidity, which, in turn, will allow the central bank to operate monetary policy more efficiently.

- An effective clearing and settlement system will lower the costs of transaction. Typically, a central bank is responsible for overseeing the economy's payment and settlement system and is required to support it through liquidity facilities to preempt risks to the payment system. This is especially the case for real-time gross settlement, which requires a larger amount of liquidity during the day to affect same-day and intraday settlements.

- Codes of conduct and standards of transactions in the market need to be understood and followed by all participants, especially the procedures and their obligations to participate in the market. Also, the tax system should support market operations.

- An interbank offer rate needs to be developed to provide a benchmark for market transactions; that is, borrowing and lending in the money market. The interbank offered rate is the base lending rate banks charge each other in the wholesale money market.

- $\quad$ For example, London Interbank Offered Rate (LIBOR) is an average of interbank deposit rates stated to be offered by members of the British Bankers Association. There are 15 different LIBOR rates, each corresponding to varying maturity dates and currencies. Bangkok Interbank Offered Rate (BIBOR) is the Thai Baht interbank rate, similar to LIBOR in London, and Kuala Lumpur Interbank Offered Rate (KLIBOR) in Malaysia. BIBOR consists of eight tenors from overnight to 1 year. The rate is the contributing bank's offer to lend baht funds to prime banks on an unsecured basis in the Bangkok interbank market just prior to 11 a.m.

Source: Authors.

Standing facilities can serve as an interest rate corridor for the interbank market once interest rates are liberalized. If new tools for liquidity injection, such as collateralized loans or repos, can be set up, the current loan window could serve as the lender of last resort facility, at penalty rates.

When necessary, the CBM could use foreign currency swaps to inject or absorb liquidity. These are similar in many ways to a repurchase agreement in domestic securities, the main difference being that local currency is exchanged for foreign currency, rather than domestic securities. The central bank can transact the swap over-the-counter, either calling banks to ask for quotes or through brokers. 
Counterparties can include onshore and offshore commercial banks. Standard tenors range from overnight to 1 year, but are usually more concentrated on the shorter end (up to 3 months).

\section{F. Data Requirements for Monetary Policy}

To operate monetary policy, the CBM must have high quality statistics and data. The main macroeconomic indicators are subject to error that can be large or small depending on the efficiency and reliability of the data collection process. This is a typical but serious problem in many developing countries, forcing policy makers and central banks to rely on weak data when making policy decisions. A case in point is the GDP data that should be available quarterly for monetary policy decisions.

High quality, timely data will enhance the CBM's ability to reduce risks in monetary policy operations and increase operational efficiency. Data on activities in the money markets, and price and trading volume in the foreign exchange market are needed on a real-time basis for the day-to-day operation of monetary policy. Long series of macro data are essential for developing macroeconomic tools and models to analyze the economy and support policy decisions. These are also lacking in Myanmar, as is the capacity of CBM staff to do quantitative analysis and forecasting.

Unexpected external shocks or volatility in exchange rates and commodity prices can upset economic forecasts and take the economy some distance from its expected path. Monetary policy typically affects the economy with a lag, as it takes time for changes in interest rates to filter down to real activities. Lower interest rates can lead to increased borrowing, spending, and demand for goods and services, but it takes time to produce additional outputs to satisfy the increase in demand. Because of lags in monetary transmission, monetary policy needs to be forward-looking and based on a view of the economic outlook. The outlook itself is derived from an assessment of current economic information, models of the relationships between economic variables, and the anticipated effects of policy actions. Risks to the outlook are factors that could lead the projection to go off track.

One challenge of monetary policy is to interpret current data on the economy and financial markets and constantly anticipate developments. The CBM regulates banks and has the authority to require banks to submit financial data. But bulk of this data is compiled with more than a 1-month lag. Data compiled by different departments and authorities outside the CBM are of different quality and standards, and in most cases, cannot be reconciled. The central bank's database presently is not supportive of monetary policy operations. At a minimum, efforts to improve data should include accurate and timely data on prices, output, balance of payments, employment, financial and monetary conditions, and liquidity in the money markets for both foreign and local currencies. In addition, as government fiscal policy operations will have direct implications for monetary policy, the CBM needs to monitor data on government revenues, expenditures, fiscal deficits, and financing.

In most countries, different agencies compile different data at varied frequencies. Central banks compile monetary and financial data with input from banks and financial institutions. Other major data sources include the departments of statistics, customs, revenue, and the ministries of finance, commerce, and other agencies. Data validation and reconciliation are needed to ensure consistency of the data. 


\section{G. Establish a Clear and Transparent Monetary Policy Process}

Monetary policy is more efficient when markets understand policy objectives and the links between monetary policy measures and these objectives. For the CBM to achieve this, it can adapt for its own reserves money targeting the sort of decision making processes many central banks operating inflation targeting use. To this end, a monetary policy board consisting of five to seven members should be formed based on the law or on the authority of the central bank governor. The founding members may initially be senior staff members and may gradually be replaced by or enhanced with external members, who can add broader and independent views to the policy process. That said, conflict of interest must be avoided in appointing outside members to the monetary policy board. It is important that this board is different to the central bank council, as it will have a different set of expertise, and be independent. The CBM's governor should chair the monetary policy board and its meetings.

An advanced timetable for board meetings must be set up and publicly announced. From various countries' experience, it should ideally meet once every 6 to 8 weeks. But the chair can call additional policy board meetings as needed. Once the schedule is set, the meeting preparation process should be carefully planned to foster effective policy decisions. In preparation for policy board meetings, internal mini meetings should be structured for data sharing among departments to identify macroeconomic and stability issues requiring discussion and policy action. In addition, the CMB should work closely with other bodies, such as the ministries of finance and of commerce, to set overall economic objectives. It should also consult with other agencies responsible for economic data and forecasting to receive a more complete view of overall economic conditions and outlook.

After each policy meeting, decisions should be released to the public. This will increase the central bank's credibility in the longer term. All members of the monetary policy board should contribute to the minutes of the meetings and its policy statement to explain decisions. Central banks can build credibility by hitting announced monetary targets. Thus, the CBM should release periodic monetary policy reports, indicating its intentions for monetary policy, as well as explaining discrepancies between actual performance and targets.

\section{H. Monetary and Fiscal Policy Coordination}

Monetary and fiscal policy need to be well-coordinated to achieve overall economic objectives. Under the new central bank law, the CBM is an entity separated from the Ministry of Finance and has been given more functional independence to operate monetary policy. However, the CBM should closely coordinate with the ministry on financing the budget deficit and its implications. Coordination has to be supported by a structured institutional and operating arrangement that allows the two institutions to formally share views and set policy directions. For monetary policy, the CBM and the Ministry of Finance together could set consistent targets of monetary and fiscal policies concerning growth, inflation, and fiscal deficit levels. They could facilitate and share information and forecast variations in government balances. The central bank should recommend alternative sources of fiscal deficit financing to limit central bank credit to the government. The CBM and the Ministry of Finance should also coordinate the country's debt profile, issue government bills in the primary market, and jointly develop the secondary markets in government securities, as both the central bank and the ministry will have to rely on these markets for fiscal and monetary operations. Close coordination of monetary and fiscal policies will go a long way to improving the efficiency of the CBM's monetary policy operations and limiting the longer term risk associated with outsized fiscal deficits and debt. 


\section{V. $\quad$ CENTRAL BANK OF MYANMAR AS LENDER OF LAST RESORT AND ITS DEVELOPMENT ROLE}

Under the new central bank law, the CBM is responsible for bank regulation and supervision and the provision of safety nets through emergency liquidity assistance as well as being involved in the oversight of the payment system. Central banks in many economies in the early stage of development also have a development role in promoting growth. Under the new central bank law, the CBM is required not only to reform its monetary process, but also to introduce international standards of financial supervision and of oversight for the payment system. This section looks at the CBM's roles in maintaining financial stability and, in particular, its role as the lender of last resort as well as its roles in the oversight of the payment system and in development.

\section{A. Financial Stability and Lender of Last Resort}

Central banks have always had a keen interest in the stability of the banking system and the safety and efficiency of the payment and settlement systems. In the case of central banks, like the CBM, that have a mandate in financial supervision, maintaining financial stability requires two main roles. The first is to ensure solvency of individual banks through effective banking regulation and supervision. The second is to ensure the soundness and the stability of the whole financial system through macroprudential supervision, payment system oversight, and as lender of last resort. The latter is to prevent a small problem in a finance sector from becoming a systemic crisis.

Myanmar has its own legacy of financial crisis and instability. The country demonetized its currency in May 1964, November 1985, and September 1987. It faced a systemic crisis and bank runs in 2003, the effects of which are still being felt. A lesson from these episodes is the importance of liquidity management and emergency lending by the central bank.

The key approach for the central bank to ensure financial stability is by acting as a lender of last resort. Last-resort lending includes the provision of liquidity to support individual financial institutions when they experience exceptional funding difficulties; and to cover temporary shortfalls in settlement balances that can arise in their daily settlement of payments. This function aims to overcome a shortfall in liquidity of individual financial institutions, which can have a domino effect or pose a systemic risk to the overall financial system.

The "bank run" is the classic example of systemic risk, a situation where a bank's failure due to its inability to meet its obligation on deposit withdrawal causes other banks to fail. The underlying cause of the chain of subsequent failures is the interconnectedness of banks: they lend, borrow, and hold deposits with each other as well as make payments through the interbank clearing system. One bank's default on an obligation may have a knock-on effect on another bank's ability to meet its obligations to other banks.

Moreover, to reduce the incentives of financial institutions for taking excessive risks, an effective system of banking supervision, along with prudential regulations, needs to be in place. This would not only help the CBM ensure the ability of individual banks to cope with periods of stress, but also monitor risks and detect vulnerabilities in the financial system as a whole. As a traditional tool complementing prudential regulations, macroprudential measures, which focus on financial risks at a macro level and aim at strengthening financial stability, could be applied. More specifically, caps on the loan-to-value ratio and on the debt-to-income ratio are useful macroprudential measures for 
addressing credit risks, while limits on net open positions are one of the liquidity-related macroprudential tools that central banks employ to curb excessive exposure.

Another role that the CBM, according to its mandate, can contribute to financial stability is ensuring an efficient payment and settlement systems. A properly functioning payment system will enhance finance sector stability, reduce transaction costs in financial intermediation, improve financial market liquidity, and facilitate the conduct of monetary policy.

Basic lending facilities and operations that the central bank can put in place to support the lender of last resort role are as follows:

\section{(i) Standing facilities}

This is the liquidity facility from which financial institutions can borrow (or deposit funds) from central banks overnight to help adjust their liquidity position at the end of the business day. The securities that can be used as collateral are high-quality ones, including those issued or guaranteed by the government and local governments, deposit accounts held at the CBM, and, if available, corporate bonds (the latter being subject to minimum credit ratings). Interest rates on standing facilities should equal the policy rate, plus or minus a certain margin depending on whether the financial institution borrows or deposits. The rates charged on standing facilities must be designed to ensure that the interest rate corridor is sufficiently wide to encourage market participants to obtain the liquidity they need from interbank markets, rather than from central banks, but narrow enough to ensure that market interest rates will fluctuate within an acceptable band.

Standing facilities provide banks with a reliable source of liquidity should they need to fund end-of-day obligations that can routinely arise in the daily settlement of payments. In the absence of this facility, it is not clear that alternative facilities can provide a reliable source of liquidity in all circumstances. Thus, standing facilities are an important mechanism to safeguard money market stability and contribute to the safe and efficient operation of the payment and settlement systems.

\section{(ii) Emergency lending facilities}

While standing facilities are intended to address a temporary and systemic lack of liquidity in the financial system, emergency lending facilities (ELFs) provide longer term support to solvent financial institutions experiencing severe and persistent liquidity problems, which may lead to insolvency and bank runs.

The basic rationale for central banks to provide ELFs is based on the activities of financial institutions, particularly deposit-taking institutions, which are vulnerable to a sudden loss of depositor confidence. The liabilities of banks generally comprise a large amount of customer fixed-value deposits, which can be redeemed at short notice, while their assets typically comprise longer term loans to households and businesses. The maturity mismatch between assets and liabilities can lead to insolvency and liquidity crises if there is a large and sudden increase in the redemption of deposits even if the institutions are fundamentally sound. This is because banks' assets can be liquidated only with difficulty and are subject to considerable discounts.

Furthermore, the interbank market may not function efficiently in a time of financial distress as participants may become more cautious. Banks will then be reluctant to lend among themselves if they have incomplete information about the solvency of other banks, even though they may be sound. As a 
consequence, reduced lending in the interbank market could lead to a sharp rise in interest rates. To preempt this, central banks need to be ready to provide ELFs.

Although ELFs are important, their effectiveness depends on the willingness of financial institutions to borrow from central banks. In general, financial institutions are reluctant to do this not only because this source is costly relative to the market, but also because of the "stigma problem" (market participants may see such borrowing as a sign of weakness). To avoid sending a negative signal on temporarily illiquid but otherwise healthy financial institutions, central banks may consider disclosing only a limited amount of information about ELF activity.

Another concern regarding ELFs is that they can create moral hazard, as they make financial institutions lax on liquidity management. They can also blunt depositors' incentives to monitor financial institutions and result in a more fragile financial system. To guard against moral hazard, central bank lending should be based on good collateral with a well-targeted penalty rate charged. These policies make ELFs unattractive in normal times, but more attractive under stress conditions. Under the new central bank law, it is clear that the CBM may provide an ELF to a bank that wishes to improve its liquidity at appropriate interest rates for periods not exceeding 92 days, provided that the bank is solvent and can provide adequate collateral to support the loan, and that such assistance is necessary to preserve the stability of the financial system as a whole.

In the event of a crisis, the CBM's most crucial function is to ensure that problems in individual institutions do not worsen into a systemic banking crisis. In Myanmar's banking crisis in 2004, triggered by the collapse of a succession of informal finance companies, not only was the provided support insufficient, but additional measures imposed by the government made the situation worse. These included restrictions on deposit withdrawals, accelerated collection of loans, and tightened capital requirements, which massively damaged public confidence and transmitted a problem in the finance sector to the real economy.

Against this background, some lessons learned could be useful for designing the new ELFs:

- Confidence is key. Restoring confidence in the financial system during a crisis is a central bank's top priority. The new ELFs must enable the CBM to provide prompt and sufficient liquidity support to restore confidence in the financial system. Confidence is essential for the stability of the financial system; it is also vital for supporting recovery from a crisis.

- Limit moral hazard. The liquidity standing facility the CBM provides as lender of last resort may create moral hazard. That is, banks may be tempted to take excessive risks, as they know that the CBM provides a safety net. To limit such unintended consequences, the central bank must strengthen prudential regulation and supervision, especially in loan classification and provisioning, capital adequacy, and related-party lending. In addition to prudential regulations and supervision, the central bank should operate the lender of last resort function only when absolutely necessary, and the facility should be made available only at penalty rates.

- Crisis resolution mechanisms and infrastructure. The CBM needs a clear plan that defines the resolution process and mechanism as well as the scope of authority of the CBM and related government agencies to reduce ambiguity and enhance the effectiveness and the timeliness of resolution management. As well as the resolution plan, the development of the capital market could provide an alternative pool of liquidity for banks. This is because the sale of government bonds is an important source of liquidity available for financial institutions 
during times of distress. Without the capital market, the government would be the only buyer of these bonds, which it might not be able to afford due to a lack of cash in hand.

\section{B. Payment System Oversight}

A safe and efficient payment system is fundamentally important for economic and financial activities, monetary policy implementation, and the country's financial stability as a whole. Ensuring efficiency in the payment system is therefore a key central bank responsibility. The CBM should therefore play a major role in the development of the country's payment system, not only to ensure that market needs are met, but also to guarantee oversight of the system to minimize risk, especially systemic risk, and ensure fairness for all parties.

In conducting this oversight role, the CBM should develop short- and long-term payment system strategies. It should consider establishing a payment systems committee to set up payment system policies consistent with business and technological development. This will promote safe, efficient, and smooth operations, which are needed to support the rising level of transactions. The committee should be responsible for policy on the oversight of payment systems to ensure that the CBM oversees payment systems and payment service providers, to safeguard the safety and efficiency of payment systems, and to foster monetary and financial stability.

Myanmar has a cash-based economy. Though high-value transactions can be paid by check, the clearing system is still a manual, paper-based operation. This method is subject to errors, and delays are frequent in the clearing process, impeding effective financial market operations. Check volume is expected to rise as the economy grows. Delays in check clearing could pose risks to the check payees and an even greater risk to the financial system as a whole. To support economic expansion, the CBM should take a leading role in developing electronic payment systems, including an electronic check clearing system, an electronic funds transfer system, such as a real time gross settlement system.

Real time gross settlement will facilitate a large volume of funds transfer between accounts held at the CBM by financial institutions and government agencies. Commercial banks can also perform third-party funds transfer on behalf of clients wanting to transfer funds to accounts at other banks. Under the system, transactions are settled on a gross basis, whereby each transaction simultaneously creates an account debit for the payer bank and an account credit for the payee bank on an item-by-item basis, and the funds transfer is completed immediately. The system would help minimize settlement risk and systemic risk; it is also more cost effective in terms of documents, processes, and human error.

Initially, the main objective of the CBM in supervising the check clearing system is to establish a liquidity supervision mechanism to ensure the smooth operation of the settlement system, and ensure fairness for banks that provide the services as well as customers' protection. The CBM should play this role by issuing operating guidelines for banks providing payment services.

With support from the Japan International Cooperation Agency, the CBM has been developing an automatic clearing house to facilitate electronic payments in Myanmar as well as support growth in business transactions and future activities. In this connection, the CBM should consider supporting the transition toward a more electronic-based payment systems, including developing cost and system coverage, and supporting laws and legal frameworks for electronic payment systems. In the longer term, establishing guidelines to improve the efficiency of payment 
systems oversight to fit with ongoing changes, as well as promoting the use of electronic payment as an alternative to cash will be challenging for the CBM, because the country has been under a cashdominated environment for a long time.

\section{The Central Bank of Myanmar's Development Role}

Central banks often have an additional role in less developed economies in which domestic financial systems are not yet mature, which is to ensure that monetary policy and government development policies are aligned.

In Myanmar, the domestic banking sector is still developing and not yet able to effectively perform intermediary functions. The number of entrepreneurs with access to credit is still very limited. To extend access to a wider segment of businesses, especially in priority sectors, the CBM could act as a banker to commercial banks by extending loans to businesses facing liquidity difficulties borrowing through commercial banks.

Two tools are available for this. The first is a refinancing facility at a central bank that is mostly used in the first stage of a country's financial and economic development. Through this facility, banks provide loans to designated priority sectors and then refinance them with the central bank under specific criteria and conditions. Normally, the loans are short-term and used for revolving finance. The CBM could set a certain amount of money for this window, with interest charged at levels not much lower than the market rate to limit the impact on monetary policy.

The CBM could ask banks to provide credit plans and give guidance to banks on the sectors they should focus their businesses on, comment on the credit plans, and ask for revisions, where needed. Banks would be required to report credit operations against their plans, citing the reasons for any misses. The report could be submitted quarterly or biyearly. If credit planning is adopted, the CBM must implement this policy carefully because it forces banks to operate with unwanted risks, which may seriously affect the overall health of the banks or, worse, lead to financial turmoil.

In performing development functions, the CBM must ensure that its prime responsibility in safeguarding macroeconomic stability is not compromised. In our opinion, the CBM should play a development role only in the early or transition stage. In the long-term, this role must be reduced as the economic and financial system becomes better developed and market mechanisms operate more fully. In this regard, the CBM should focus on strengthening and streamlining the regulatory framework to support a sustainable economy.

\section{OPERATIONAL STRUCTURE AND CAPACITY BUILDING}

The extensive functions and duties authorized by the new central bank law are comprehensive, modern, and innovative compared with the old law. The CMB's main challenge is to carry out these duties with efficiency and reliability. The central bank needs an appropriate organizational and management structure to enable it to successfully undertake its new functions and duties. And it needs to constantly review and modify its organizational structure to meet the changing needs of its new duties and responsibilities.

Organizational structure defines the lines of authority, chain of command or supervisory relationships, allocation of resources, operational workflow, groupings of employees with diverse 
functions and decision processes. A well-designed organizational structure will allow efficient communication, encourage departments and groups within the CBM to work together, and establish a hierarchy of responsibilities. Organizational structuring involves a wide range of factors that need to be considered, as illustrated in the figure below.

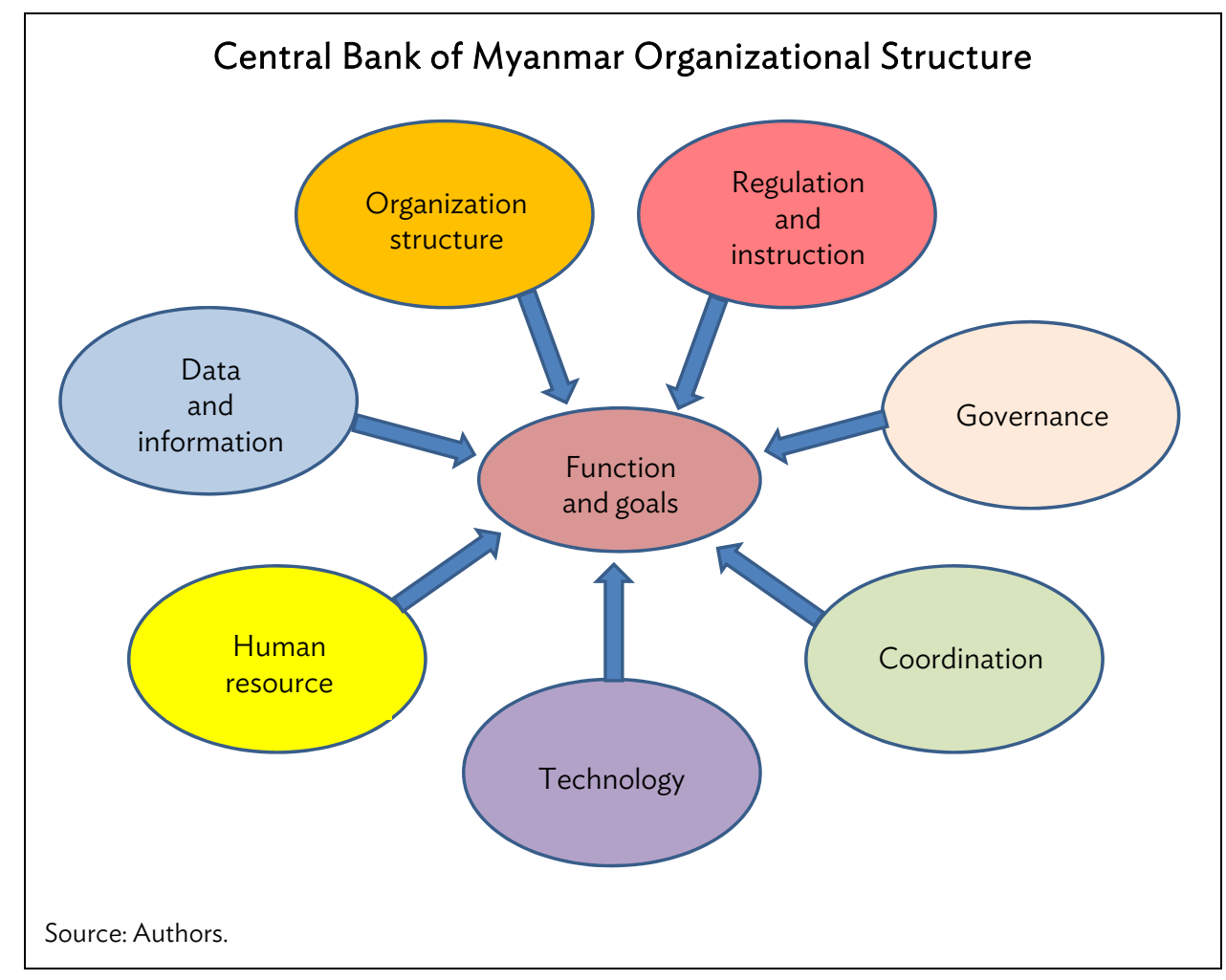

The task ahead is to equip the CBM with the capacity and work processes to operate effectively, with priority given to monetary policy, banking supervision, reserve management, and payment systems. As well as departmentalization and work processes, the CBM should provide clear objectives, specifications, distribution of rights and responsibilities among different participants within the central bank, including rules and procedures for making decisions. Once the CBM sets organizational objectives, it must then define and assign oversight responsibility and identify high-level processes to ensure the organization meets its objectives. More simply, the central bank should set working processes that keep the organization alive, regulating internal information flows and decision processes to ensure its responses are timely and appropriate.

New information technologies are urgently needed to facilitate the CBM's operations. The central bank needs an effective communication network to help coordinate decisions and facilitate consultation between senior officers and staff working in the Yangon office and headquarters in Naypyitaw. These should be made available to all concerned people in the CBM, but in different degrees of detail, to ensure that everyone understands the same policies, procedures, and control mechanisms. Access should be simple and straightforward.

In terms of disclosure and transparency, the CBM should clarify and publicize the roles and responsibilities of the board, committee members, and management to ensure a degree of accountability. Disclosure of information to the public should be timely and balanced. These are standard good governance procedures. 


\section{Central Bank of Myanmar and Capacity Building}

Capacity building is essential to institutional reform. Capacity building generally refers to education and training programs to address a lack of qualified personnel and human resources. But the concept of capacity building has evolved in recent years toward a broader context that covers innovation initiatives in institutions, data and information systems, technology, and human resources.

To support the reform of its institutional roles, the CBM must rapidly build new capacity to allow it to effectively assume its new responsibilities. To this end, the central bank should formulate a sequenced and detailed capacity development program for its senior officers and staff. The program should include exposure visits by senior management and key line operational staff to central banks abroad and general training on central banking roles and functions on a bank-wide basis. The focus should be on practical implementation of the CBM's new responsibilities. Selected broader international expertise may be required to support reform implementation as Myanmar's economy becomes more open and integrated with the global economy. ${ }^{3}$ The primary objective of training courses should be to enhance the capacity and ability of executives to conduct monetary policy, macroeconomic policy management, banking supervision, payment and settlement supervision, reserve management, and foreign exchange operations. The target participants should be directors or senior directors of all departments and provincial branches. Programs for postgraduate study in economics, finance, and banking operations for selected midlevel staffs will be required in the longer term. Banks, both private and state, also require general capacity building among senior managers as well as staff.

The CBM should formulate a concrete plan to build staff capacities, both immediately and for the longer term. Monetary policy training courses are urgently needed to enhance the CBM's staff skills for implementing monetary policy and operations, including macroeconomics, monetary analysis and forecasting, foreign exchange intervention, policy communication and dissemination, and analyzing the implications of external shocks. Training in the operation of the foreign exchange market and reserve management, including investment strategies, risk-based analysis, and back-office business are also urgently needed for CBM staff, in preparation for foreign exchange pooling and reserve management. In the longer term, capacity building must be structured to meet the following requirements:

- Risk-based approach for financial supervision and regulation;

- Macro prudential and financial supervision;

- Financial market surveillance and supervision;

- Macroeconomic accounting and a forecasting system;

- Liquidity, financial intermediation, and monetary policy; and

- Time-series analysis for forecasting and macroeconometric modeling and computer software.

The CBM, in coordination with the International Monetary Fund, World Bank, and the Asian Development Bank, could set up these training courses as well as seminars and workshops. However, the capacity plan should allow the CBM to identify its human resource needs, and hence, areas for capacity development. The courses should be supported by comprehensive development of the central bank's database to allow capacity building using real time data.

3 The Asian Development Bank's capacity building program for high-ranking officials of the State Bank of Vietnam held in August 2012 could be similarly organized for CBM officers. 
Centralizing activities relating to data management is recommended. Data collection and compilation should be separated from policy formulation to increase transparency and efficiency in data management. A benefit of centralized data management is to reduce interdepartmental bureaucracy in the sharing of information and provide clear accountability between those collecting data and those using it. Operational staff could then focus on core departmental functions rather than data management. There are many experiences in data management in central banks. Box 7 outlines a possible data development plan.

\section{Box 7: Guiding Principles for Data Management}

Key features of a good data management system that can guide the CBM include:

Data governance. High-level executive data stewardship should be part of a data governance function that takes responsibility for strategic planning, monitoring, and control of data management. The stewardship role involves understanding strategic enterprise data needs, the development and approval of data policies, and data structure and procedure, as well as establishment of roles and ensuring regulatory compliance.

Data ownership and data custodianship. The CBM needs to clarify the issue of data ownership within the central bank itself. Data belongs to the CBM as an institution and not to any individual department of the central bank. Unless otherwise specified, data will be accessible to any user with an appropriate level of security. To accomplish the function, if resources permit, a separate department should be set up for data custodianship.

Data warehousing. To collect, cleanse, transform, and store data from a variety of sources for the needs of the entire organization, the CBM could consider developing an enterprise data warehouse. This integrates all business operations data and supports historical and analytical business requirements. Setting up an enterprise data warehouse will increase the capabilities of the CBM to query, analyze, and report its findings in support of its policy decisions. It will also reduce redundant and uncoordinated requests for information from departments, and discourage unclear classification and definitions of requested information.

Data quality. To ensure high quality data (based on accuracy, coherence, timeliness, and accessibility consistent with international data frameworks), the CBM needs to set up written guidelines for the format of data, validation rules, and submission due date of each required input. Such guidelines must be announced to the public or at least to the data providers for references.

Reference codes and classification standard. Wherever possible, standard country and currency codes (both national and international) and references must be used. With standard codes, the CBM's information will be comparable with other countries' reports.

Data security. Data reported to the CBM could include both confidential and public data. The CBM must have data security rules defining what is confidential data, who can access this data, and how to request it.

Data access. Data management systems must provide wide accessibility for all user groups. However, output formats and the level of information could be different for particular classes of users (that is, the CBM staff and the general public, and usually on a need-to-know basis). The CBM should provide a data release schedule with a clear presentation of data-and in formats that are easy to understand.

Cross-agency coordination. Sharing data among government agencies should be encouraged; this will reduce costs in data management for government agencies and data providers.

Source: Authors. 


\section{CONCLUSION}

Under the Central Bank Law of 2013, the CBM's wide-ranging tasks and duties were mandated to include exchange rate management, monetary policy, financial supervision, and payment system oversight. To accomplish this, a comprehensive reform of the CBM's functions is needed, and this needs to be supplemented by restructuring the organization and capacity building to successfully implement the reform. This needs to proceed in steps, the first of which must enable the CBM to carry out basic central banking functions, as required by law, and at a level of operational complexity consistent with its capacity in the financial markets and that of other players. The comprehensiveness of the first step should be such that it provides sufficient policy leverage and a framework to support the operation and the development of a market-based economy. As the sophistication of the economy and financial markets increases, the next stages can support the economy's development at a higher level. level:

Here are eight areas of reform that will enable the CBM to carry out its functions at a basic

- A well-defined monetary policy framework that is operationally consistent with the managed floating exchange rate regime

- Market-based instruments to implement monetary policy

- The essential financial markets to enable the operation of monetary policy and to support the transmission mechanism

- A monetary policy process to guide decision making in a structured manner; centralized official reserves holdings at the CBM to aid exchange rate management, and backed by a modern back office and accounting facilities

- A system of approval-based foreign exchange controls to enable greater private sector access to foreign exchange under a policy set up by the CBM

- Liquidity-supporting facilities to serve the CBM's role as lender of last resort and in payments system oversight

- Organizational change and capacity building to support the CBM's new roles

- Data development and management as part of the capacity building requirement

Accomplishing this will be a delicate and demanding task, especially given the CBM's long absence from a market-based economy. Even so, the experience of other countries with similar reforms, particularly in the ASEAN, show that these reforms could be adequately carried out with the existing staff capability at the CBM. But this does need support from a group of central bank experts.

Efforts to start these reforms quickly and systematically will go a long way toward strengthening Myanmar's macroeconomic policy capabilities. 


\section{BIBLIOGRAPHY}

Acharya, V. V., M. J. Fleming, W. B. Hrung, and A. Sarkar. 2012. Dealer Financial Conditions and Lender-of-Last Resort Facilities. http://www.efa2012.org/papers/t1e2.pdf

Adrian, T. and H. S. Shin. 2008. Financial Intermediaries, Financial Stability, and Monetary Policy. Federal Reserve Bank of New York Working Paper No. 346. New York: Federal Reserve Bank of New York.

Ahrend, R., B. Cournède, and R. W. Price. 2008. Monetary Policy, Market Excesses and Financial Turmoil. OECD Economics Department Working Papers No.597. Paris: Organisation for Economic Co-operation and Development.

Allen, F., C. Elena, and G. Douglas. 2009. Interbank Market Liquidity and Central Bank Intervention. Journal of Monetary Economics. 56 (5). pp. 639-52.

ASEAN Central Banks' Working Committee on Payment and Settlement Systems. 2011. Strategic Report to the ASEAN Central Bank Governors Meeting. http://www.aseanwcpss.org/ aseanwcpss/Documents/WCPSS\%20Studies\%20Executive\%20Summary.pdf

Asian Development Bank. 2014. Key Indicators for Asia and the Pacific 2014. Manila.

Atkinson P. and J. C. Chouraqui. 1986. The Formulation of Monetary Policy: A Reassessment in the Light of Recent Experience. OECD Economics Department Working Papers No. 32. Paris: Organisation for Economic Co-operation and Development.

Bank of England. 2008. Gilt Repo Code of Guidance. London.

- - - 2008. Operational Standing Lending and Deposit Facilities; Discount Window Facility. Bank of England Market Notice. http://www.bankofengland.co.uk/markets/money/eligiblesecurities.xls

- - 2009. The Bank of England's Oversight of Interbank Payment Systems under the Banking Act. London.

- - 2010. A Guide to the Bank of England's Real Time Gross Settlement System. London.

- - 2012. The Transmission Mechanism of Monetary Policy. London.

- - - 2012. Bank of England's Approach to the Supervision of Financial Market Infrastructures. London.

_- - 2013. The Prudential Regulation Authority's Approach to Banking Supervision. London.

Bank for International Settlements. 2013. Central Bank Payment and Settlement Services with Respect to Cross-Border and Multi-Currency Transactions. Basel.

- - . 2013. Monitoring Tools for Intraday Liquidity Management. Basel. 
Batini, N. and Y. Anthony. 2003. Hybrid Inflation and Price-Level Targeting. Journal of Money, Credit, and Banking. 35 (3). pp. 283-300.

Batini, N. and N. Edward. 2001. Optimal Horizons for Inflation Targeting. Journal of Economic Dynamics and Control. 25 (6). pp. 891-910.

Batini, N. and A. Haldane. 1999. Forward-Looking Rules for Monetary Policy. In J. Taylor, ed. Monetary Policy Rules. Chicago: University of Chicago Press. pp. 157-202.

Batini, N. and T. Kenny. 2000. Monetary Conditions Indices for the UK: A Survey. External MPC Unit Discussion Paper No. 1. London: Bank of England.

Batini, N. and D. Laxton. 2007. Under What Conditions Can Inflation Targeting Be Adopted? The Experience of Emerging Markets. Central Banking, Analysis, and Economic Policies Book Series. 11 (12). pp. 467-506.

Berentsen, A. and C. Monnet. 2008. Monetary Policy in a Channel System. Journal of Monetary Economics. 55 (6). pp. 1067-80.

Carlson, M. A., and D. C. Wheelock. 2013. The Lender of Last Resort: Lessons from the Fed's First 100 Years. Federal Reserve Bank of St. Louis Working Paper No. 56. St. Louis: Federal Reserve Bank of St. Louis.

Cecchetti, S. G. 1999. Legal Structure, Financial Structure, and the Monetary Policy Transmission Mechanism. Federal Reserve Bank of New York Economic Policy Review. 5 (2). pp. 9-28.

Central Bank of Myanmar. http://www.cbm.gov.mm/

Committee on Payment and Settlement Systems and International Organization of Securities Commissions. 2011. Principles for Financial Market Infrastructures. Bank for International Settlements Consultative Report.

Croce, E. and S. K. Mohsin. 2000. Monetary Regimes and Inflation Targeting. Finance and Development. 37 (3). pp. 48-51.

Cœuré, B. 2013. Monetary Policy and Banking Supervision. Remarks at the symposium Central Banking: Where Are We Headed? Goethe University, Frankfurt. 7 February.

Davis, E. P. 1999. Financial Data Needs for Macroprudential Surveillance-What Are the Key Indicators of Risks to Domestic Financial Stability? Bank of England, Centre of Central Banking Studies.

Dent, A. and W. Dison. 2012. The Bank of England's Real-Time Gross Settlement Infrastructure. Bank of England Quarterly Bulletin. Q3.

Devereux, B. M., R. L. Philip, and X. Juanyi. 2006. Exchange Rates and Monetary Policy in Emerging, Market Economies. The Economic Journal. 116 (511). pp. 478-506. 
Dudley, W. C. 2013. Why Financial Stability is a Necessary Prerequisite for an Effective Monetary Policy. Remarks at the Andrew Crockett Memorial Lecture, Bank for International Settlements 2013 Annual General Meeting. Basel. 23 June.

Ehrmann, M., L. Gambacorta, J. Martínez-Pagés, P. Sevestre, and A. Worms. 2001. Financial Systems and the Role of Banks in Monetary Policy Transmission in the Euro Area. European Central Bank Working Paper No. 105. Frankfurt: European Central Bank.

European Central Bank. 2008. The Role of Banks in the Monetary Policy Transmission Mechanism. ECB Monthly Bulletin. August.

Financial Stability Board, International Monetary Fund, and Bank for International Settlement. 2011. Macroprudential Policy Tools and Frameworks: Progress Report to G20. http://www.bis .org/publ/othp17.pdf

Freixas, X. and J. Jorge. 2008 The Role of Interbank Markets in Monetary Policy: A Model with Rationing. Journal of Money, Credit and Banking. 40 (6). pp. 1151-76.

Fuentes, J. R. and L. A. Ahumada. 2003. Banking Industry and Monetary Policy: An Overview. Central Bank of Chile Working Paper No. 240. Santiago: Central Bank of Chile.

Goodfriend, M. and K. Robert. 1988. Financial Deregulation, Monetary Policy, and Central Banking. Federal Reserve Bank of Richmond's Economic Review. 74 (3). Richmond: Federal Reserve Bank of Richmond.

Goodhart, C. A. E. 1987. Why Do Banks Need a Central Bank? Oxford Economic Papers. 39 (1). pp. 75-89.

-_- 2000. The Organisational Structure of Banking Supervision. FSI Occasional Papers No. 1. Basel: Financial Stability Institute, Bank for International Settlements.

Goodhart, C. and D. Schoenmaker. 1995. Should the Function of Monetary Policy and Banking Supervision Be Separated? Oxford Economic Paper. 47 (4). pp. 539-60.

Hall, S., C. Salmon, T. Yates, and N. Batini. 1999. Uncertainty and Simple Monetary Policy Rules: An Illustration for the United Kingdom. Bank of England Working Paper No. 96. London: Bank of England.

Hanif, M. N. and M. F. Arby. 2003. Monetary and Fiscal Policy Coordination. MPRA Paper No. 10307. Germany: University Library of Munich.

Hildebrand, P. M. 2006. Monetary Policy and Financial Markets. Remarks at the Schweizerische Gesellschaft für Finanzmarktforschung. Zurich. 7 April.

Hitchman, K. G. 2010. Organizational Structure and Functions within Intermediary Organizations: A Comparative Analysis. Report prepared for the Canadian Water Network. http://www .cwn-rce.ca/assets/uploads-2/Knowledge-Mobilization/Comparative-analysis-of-intermediary -organizations.pdf 
Hood, C. 1995. The New Public Management in the 1980s: Variations on a Theme. Accounting, Organization and Society. 20 (2/3). pp. 93-109.

International Monetary Fund. 2013. Guidance Note for the Liberalization and Management of Capital Flows. Washington, DC.

- - Various years. IMF Country Reports, Myanmar: Article IV Consultation. Washington, DC.

Joyce, M. and A. Meldrum. 2008. Market Expectations of Future Bank Rate. Bank of England Quarterly Bulletin. 48 (3). pp. 274-82.

Kashhyap, A. K., and J. C. Stein. 1995. The Impact of Monetary Policy on Bank Balance Sheets. Carnegie-Rochester Conference Series on Public Policy. 42 (1). pp. 151-95.

King, M. 2013. Monetary Policy: Many Targets, Many Instruments. Where Do We Stand? Remarks at the IMF Conference on Rethinking Macro Policy II: First Steps and Early Lessons. Washington, DC. 16 April.

- - . 2004. The Institutions of Monetary Policy. Bank of England Quarterly Bulletin. Autumn.

Korhonen, P. 2013. Do Macroprudential Tools Require Micro-Data? Paper presented at the Workshop on Integrated Management of Micro-Databases. Casa da Música, Porto. 21 June.

Lange, J., S. Brian, and W. William. 2003. Anticipations of Monetary Policy in Financial Markets. Journal of Money, Credit and Banking. 35 (6). pp. 889-909.

Laurens, B. and E. de la Piedra. 1998. Coordination of Monetary and Fiscal Policies. IMF Working Paper No. 98/25. Washington, DC: International Monetary Fund.

Leinonen, H. ed. 2005. Liquidity, Risks and Speed in Payment and Settlement Systems-A Simulation Approach. Bank of Finland Studies. E:31.

Liang, X. n.d. Analysis of Money Demand Theory. web.cenet.org.cn/upfile/56317.pdf

Merton, R. C., and Z. Bodie. 2005. Design of Financial Systems: Towards a Synthesis of Function and Structure Journal of Investment Management. Journal of Investment Management. 3 (1). pp. 1-23.

Mishkin, F. S. 1998. International Experience with Different Monetary Policy Regimes. IIES Seminar Paper No. 648. Stockholm. Institute for International Economic Studies.

- - . 2000. Inflation Targeting in Emerging Market Countries. NBER Working Paper No. 7618. Cambridge, MA: National Bureau of Economic Research.

Moeser, C. 2010. Israel: Monetary and Fiscal Policy. OECD Economics Department Working Papers No. 783. Paris: Organisation for Economic Co-operation and Development. 
Neyer, U. and J. Wiemers. 2003. Why Do We Have an Interbank Money Market? IWH Economic Research Discussion Paper No. 182. Halle, Germany: Halle Institute for Economic Research.

Oganesyan, G. 2013. The Changed Role of the Lender of Last Resort: Crisis Responses of the Federal Reserve, European Central Bank, and Bank of England. IPE Working Paper No. 19. Berlin: Institute for International Political Economy.

Rajabifard, A. and I. P. Williamson. 2004. SDI Development and Capacity Building. Proceedings from the 7th Global Spatial Data Infrastructure Conference. Bangalore. 2-6 February.

Reinhardt, D., A. R. Luca, and T. Thierry. 2010. International Capital Flows and Development: Financial Openness Matters. IMF Working Papers No. 1-44. Washington, DC: International Monetary Fund.

Schwarcz, S. L. 2008. Systemic Risk. American Law and Economics Association Annual Meetings. Paper 20.

Shrestha, M. B. 2008. Macroeconomic Surveillance for Monetary Policy Management in the SEACEN Countries. The South East Asian Central Banks. SEACEN Research and Training Centre. http://www.seacen.org/GUI/pdf/publications/research_proj/2008/rp70/rp70_complete.pdf

Turnell, S. 2005. Suppose There Was a Banking Crisis that Nobody Ever Heard of: Burma's* Monetary Miasma. Paper Presented to the Economics Department. Queens College, City University of New York. 2 March.

Turnell, S. and A. Vicary. 2003. Burma's Banking Crisis: A Commentary. http://www.ibiblio.org/ obl/docs/BEW2003-03.htm

Van de Ven, A. H. 1986. Central Problems in the Management of Innovation. Management Science. 32 (5). pp. 590-607.

Wells, S. 2002. UK Interbank Exposures: Systemic Risk Implications. Bank of England Financial Stability Review.

World Bank. World Development Indicators. http://data.worldbank.org/data-catalog/worlddevelopment-indicators

\footnotetext{
* ADB recognizes "Burma" as Myanmar.
} 


\section{Monetary Policy and Foreign Exchange Management: Reforming Central Bank Functions in Myanmar}

Myanmar's macroeconomic policy framework does not adequately support the new functions of the Central Bank of Myanmar. This paper identifies 10 priority areas for reform to allow the central bank to effectively perform its emerging new functions in support of economic growth and stability. These priority areas entail a three-front effort: dismantle nonmarket arrangements, especially in the finance sector; implement a monetary policy framework and operational procedures, including financial markets development; and enhance central bank policy capacity.

\section{About the Asian Development Bank}

ADB's vision is an Asia and Pacific region free of poverty. Its mission is to help its developing member countries reduce poverty and improve the quality of life of their people. Despite the region's many successes, it remains home to the majority of the world's poor. ADB is committed to reducing poverty through inclusive economic growth, environmentally sustainable growth, and regional integration.

Based in Manila, ADB is owned by 67 members, including 48 from the region. Its main instruments for helping its developing member countries are policy dialogue, loans, equity investments, guarantees, grants, and technical assistance.

$\mathrm{ADB}$ 